\title{
High-resolution urban observation network for user-specific meteorological information service in the Seoul Metropolitan Area, South Korea
}

\author{
Moon-Soo Park, Sung-Hwa Park, Jung-Hoon Chae, Min-Hyeok Choi, Yunyoung Song, Minsoo Kang, and \\ Joon-Woo Roh \\ Weather Information Service Engine, Hankuk University of Foreign Studies, 17035, Gyeonggi-do, South Korea
}

Correspondence to: Moon-Soo Park (ngeograph2@gmail.com)

Received: 25 August 2016 - Discussion started: 30 August 2016

Revised: 6 April 2017 - Accepted: 7 April 2017 - Published: 25 April 2017

\begin{abstract}
To improve our knowledge of urban meteorology, including those processes applicable to high-resolution meteorological models in the Seoul Metropolitan Area (SMA), the Weather Information Service Engine (WISE) Urban Meteorological Observation System (UMS-Seoul) has been designed and installed. The UMS-Seoul incorporates 14 surface energy balance (EB) systems, 7 surface-based threedimensional (3-D) meteorological observation systems and applied meteorological (AP) observation systems, and the existing surface-based meteorological observation network. The EB system consists of a radiation balance system, sonic anemometers, infrared $\mathrm{CO}_{2} / \mathrm{H}_{2} \mathrm{O}$ gas analyzers, and many sensors measuring the wind speed and direction, temperature and humidity, precipitation, and air pressure. The EBproduced radiation, meteorological, and turbulence data will be used to quantify the surface EB according to land use and to improve the boundary-layer and surface processes in meteorological models. The 3-D system, composed of a wind lidar, microwave radiometer, aerosol lidar, or ceilometer, produces the cloud height, vertical profiles of backscatter by aerosols, wind speed and direction, temperature, humidity, and liquid water content. It will be used for highresolution reanalysis data based on observations and for the improvement of the boundary-layer, radiation, and microphysics processes in meteorological models. The AP system includes road weather information, mosquito activity, water quality, and agrometeorological observation instruments. The standardized metadata for networks and stations are documented and renewed periodically to provide a detailed observation environment. The UMS-Seoul data are designed to support real-time acquisition and display and automatically
\end{abstract}

quality check within 10 min from observation. After the quality check, data can be distributed to relevant potential users such as researchers and policy makers. Finally, two case studies demonstrate that the observed data have a great potential to help to understand the boundary-layer structures more deeply, improve the performance of high-resolution meteorological models, and provide useful information customized based on the user demands in the SMA.

\section{Introduction}

The world population exceeded 7.3 billion in 2015 ; it is projected to increase steadily and reach 9.7 billion by 2050 and 11.2 billion by 2100 (United Nations, 2015). The urban population also increased and is expected to increase at an even greater rate. The ratio of the global urban population was over $53 \%$ in 2014 and is projected to grow to approximately $66 \%$ by 2050 (United Nations, 2014). The high population density in urban areas is inevitably vulnerable not only to disastrous meteorological and environmental phenomena, such as heavy rain/snowfall, heat and cold waves, air pollution, and strong wind, but also to manmade disasters such as the explosion or release of toxic gases (OFCM, 2004; Razafindrabe et al., 2009). Impervious surfaces in urban areas tend to amplify urban flash flooding under heavy rainfall conditions, freezing rain or snowfall disrupt transportation systems, and severe storms with lightning and high winds might result in power failures. A high population density in urban areas therefore leads to greater property damage and loss of life as a result of disastrous events. 
It is well known that the urban surface material and building morphology affect meteorology in various ways including the increase in temperature, leading to the urban heat island effect (Bornstein, 1968; Oke, 1973; Landsberg, 1981; Arnfield, 2003; Kalnay and Cai, 2003; Kim and Baik, 2005; Grimmond, 2006); decrease or increase in the temporal variation of absolute humidity due to impervious surfaces and anthropogenic water use (Unger, 1999; Kuttler et al., 2007); increase in haze, cloud, and precipitation (Bornstein and Lin, 2000; Dixon and Mote, 2003; Shepherd, 2005; Carrio et al., 2010); decrease in visibility due to anthropogenic aerosols (Cheng and Tsai, 2000; Singh et al., 2008; Nichol et al., 2010); increase in the turbulent intensity and change of wind speed due to high-rise buildings (Roth, 2000; Arnfield, 2003; Grimmond et al., 2004; Barlow et al., 2011; Song et al., 2013); decrease in solar radiation due to manmade air pollutants (Peterson et al., 1978; Robaa, 2009); increase in the sensible heat flux and heat storage due to anthropogenic heat release from the urban surface; and decrease in the latent heat flux (Nunez and Oke, 1977; Christen and Vogt, 2004; Harman and Belcher, 2006; Grimmond et al., 2009; Nordbo et al., 2012; Park et al., 2014a). When the synoptic wind becomes strong, the area receiving most of the precipitation with strong upward motion moves more downwind (Bornstein and Lin, 2000; Lin et al., 2011; Han et al., 2014).

Many countries and cities in Europe, North America, and Asia have conducted urban meteorological experiments and/or intensive observation campaigns for various purposes such as understanding urban meteorological processes and improving the predictability of urban high-resolution meteorological phenomena (Allwine et al., 2002; Cros et al., 2004; Rotach et al., 2005; Schroeder et al., 2010; Basara et al., 2011; Koskinen et al., 2011; Hicks et al., 2012; Wood et al., 2013; Nakatani et al., 2015; Tan et al., 2015). The observed meteorological variables, spatial resolution for each instrument in the network, and temporal resolution for each variable are determined according to the needs of various users: surface meteorology and service-oriented observation might be sufficient for real-time information services such as the New York Mesonet (http://www.nysmesonet.org); surface energy balance (EB) and vertical profiles are needed for advances in urban meteorology or high-quality and highresolution forecasts such as the Basel Urban Boundary Layer Experiment (Rotach et al., 2005) and Shanghai Urban Integrated Meteorological Observation Network (Tan et al., 2015); and radars are good for real-time services for severe weather and short-term forecast such as the Tokyo Metropolitan Area Convection Study for Extreme Weather Resilience (Nakatani et al., 2013, 2015).

For the purpose of high-resolution meteorological information services, the improvement of the supporting meteorological model is essential. Physics schemes, including microphysics (interactions among water vapor, cloud water, cloud ice, rain drop, snow, and graupel), cumulus (updraft, downdraft, entrainment, and detrainment in clouds), radiation (ab- sorption, emission, scattering, reflection, and transpiration in the atmosphere for radiative energy), surface (surface EB and energy/moisture transfer between the surface and ground), and atmospheric boundary-layer schemes (energy and moisture transfer between the surface and atmospheric boundary layer), interact with each other (Dudhia, 1989). Irregular surface morphologies and materials in urban areas affect the surface optical, physical, and thermal properties such as thermal conductivity, heat capacity, roughness, displacement length, albedo, and emissivity (Masson, 2006; Lee and Park, 2008; Grimmond et al., 2009). These properties change the energy partition dramatically over urban surfaces compared with rural surfaces. As a result, the modified sensible and latent heat fluxes change the boundary-layer structure due to energy and moisture interactions between the surface, underlying ground, and overlying atmosphere (Pielke, 2002).

In South Korea, the urban population ratio increased steadily from $21.4 \%$ in 1950 to $79.4 \%$ in 2000 to $82.4 \%$ in 2014; it is expected to reach $87.6 \%$ in 2050 (United Nations, 2014, 2015). The Seoul Metropolitan Area (SMA) was ranked to include the fifth largest urban area population in 2015 (Demographia, 2015). Meteorological data analyses for the period from 1960 to 2009 in the SMA show that the air temperature and precipitation increase, relative humidity decreases, and heavy rainfall events with more than $20 \mathrm{~mm} \mathrm{~h}^{-1}$ also increase (Kim et al., 2011). Recently, the SMA has experienced blackouts of more than 1.6 million houses due to failure in electric power demand prediction after extremely hot weather in autumn, massive damage from shallow landslides due to heavy rainfall in 2011 (D. W. Park et al., 2013), several inundations by flash floods (Kim et al., 2014), building damage due to strong winds such as typhoons, traffic accidents as a result of road ice, and deaths due to annual heat/cold waves (Son et al., 2012).

The Weather Information Service Engine (WISE) project was launched in 2012 to meet the needs of high-resolution meteorological information to reduce the damage to the citizens caused by extreme weather phenomena and provide useful indices customized for each user's demand in the SMA (Choi et al., 2013). To achieve these goals, scientific advances in urban meteorology and development/improvement of high-resolution meteorological models and service-specific application models are needed (Baklanov, 2006; Baklanov et al., 2008). To provide various users, such as researchers, administrators, and policy makers, with observation-based meteorological information and support the development or improvement of related models in fields of air quality, flash flood, road weather, dispersion of released dangerous matter, ecology, and energy use prediction with a horizontal resolution from several meters to several kilometers, the high-resolution Urban Meteorological Observation System network in the Seoul Metropolitan Area (UMSSeoul) has been proposed and established.

This study includes the background of UMS-Seoul through a description of the geography, topography, and land 
cover of the SMA and a review of available meteorological observation networks. We then present the objectives, details, and applications of each meteorological observation system network including the surface EB observation system, threedimensional (3-D) meteorological observation system, and applied meteorological (AP) observation system network in UMS-Seoul. The usefulness of UMS-Seoul and applicability to high-resolution meteorological information services are then demonstrated using the detailed horizontal surface meteorological field and complex boundary-layer structure.

\section{Seoul Metropolitan Area}

The SMA on the Korean Peninsula consists of three administrative provinces: Seoul Special City, Incheon Metropolitan City, and Gyeonggi Province (Fig. 1a). Seoul Special City, the capital city of South Korea, is surrounded by the Gyeonggi Province and Incheon Metropolitan City, with the highest population density of $16188 \mathrm{~km}^{-2}$ (Table 1). Incheon Metropolitan City is located between Seoul Special City and the Yellow Sea. The Gyeonggi Province has the highest population (11.4 million people) and the largest area $\left(10184 \mathrm{~km}^{2}\right)$ but the lowest population density $\left(1119 \mathrm{~km}^{-2}\right.$; Table 1).

The SMA has very complex geography, topography, and land cover. Gyeonggi Bay is in the Yellow Sea in the west of the SMA and has a very irregular coastline. The Yellow Sea is an important moisture source in the case of heavy rainfall, snowfall, or heterogeneous reactions among long-rangetransporting air pollutants (Chung and Kim, 2008; Cayetano et al., 2011; Cha et al., 2011; S.-U. Park et al., 2011, 2013; Jeong and Park, 2013). The western part of the SMA comprises relatively low-lying farmland or urban areas, while the eastern part contains high-altitude mountain ranges, some of which are higher than $1000 \mathrm{~m}$ in Domain 1 (Fig. 1a). Most mountains in South Korea are covered with forest. Highly populated areas range from Incheon Metropolitan City to Seoul Special City, indicated in Domain 2 (Fig. 1b). The Han River flows from east to west and divides the SMA from Seoul Capital City. Seoul Capital City is surrounded by several high mountains $>500 \mathrm{~m}$ in altitude: the Bukhan, Dobong, Surak, and Gwanak mountains in the northern part and the Cheonggye and Bulam mountains in the southern part. There is a small mountain (262 $\mathrm{m}$ high) in the center of Seoul Special City (Fig. 1b).

Figure 2 shows the simplified land use in the SMA (Domain 1) and highly populated area (Domain 2) with $90 \mathrm{~m}$ horizontal resolution. Forest covers $41.9 \%$ of the area; croplands including pasture and grassland cover $21.5 \%$; water bodies including seawater and inland water cover $20.9 \%$; urban areas including residential, industrial, and commercial areas cover 8.6\%; and wetlands cover $5.0 \%$ in Domain 1 (Table 2). In Domain 2, forest covers $36.0 \%$, urban areas cover $28.3 \%$, croplands cover $20.6 \%$, wetlands cover $8.6 \%$,
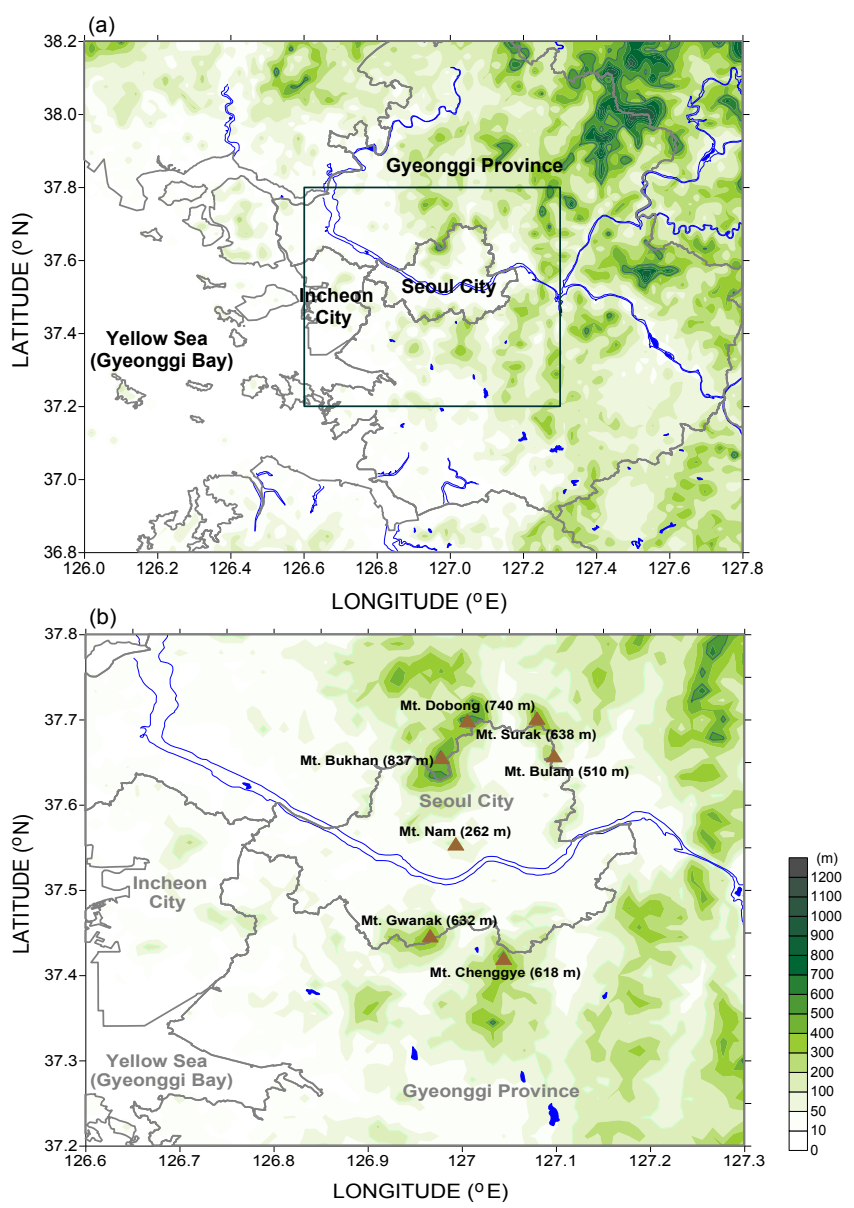

Figure 1. (a) Geography and topography of the Seoul Metropolitan Area with administrative boundaries. (b) Enhanced geography and topography with major mountains in a highly populated region shown by the rectangle in panel (a).

Table 1. Area, population, and population density statistics in SMA (http://kosis.kr).

\begin{tabular}{lrrr}
\hline & Seoul & Incheon & Gyeonggi \\
\hline Area $\left(\mathrm{km}^{2}\right)$ & 605 & 1010 & 10184 \\
Population & 9794304 & 2662509 & 11379459 \\
$\begin{array}{l}\text { Population density } \\
\left(\mathrm{km}^{-2}\right)\end{array}$ & 16188 & 2588 & 1119 \\
\hline
\end{tabular}

and water bodies cover $6.4 \%$ of the area (Table 2). Most wetlands are tidelands on the border between the continent and Yellow Sea. More than $40 \%$ of Seoul Capital City is residential or commercial areas, approximately $30 \%$ is covered with forest, and $\sim 10 \%$ is covered with roads and rivers (Fig. 2 b). 

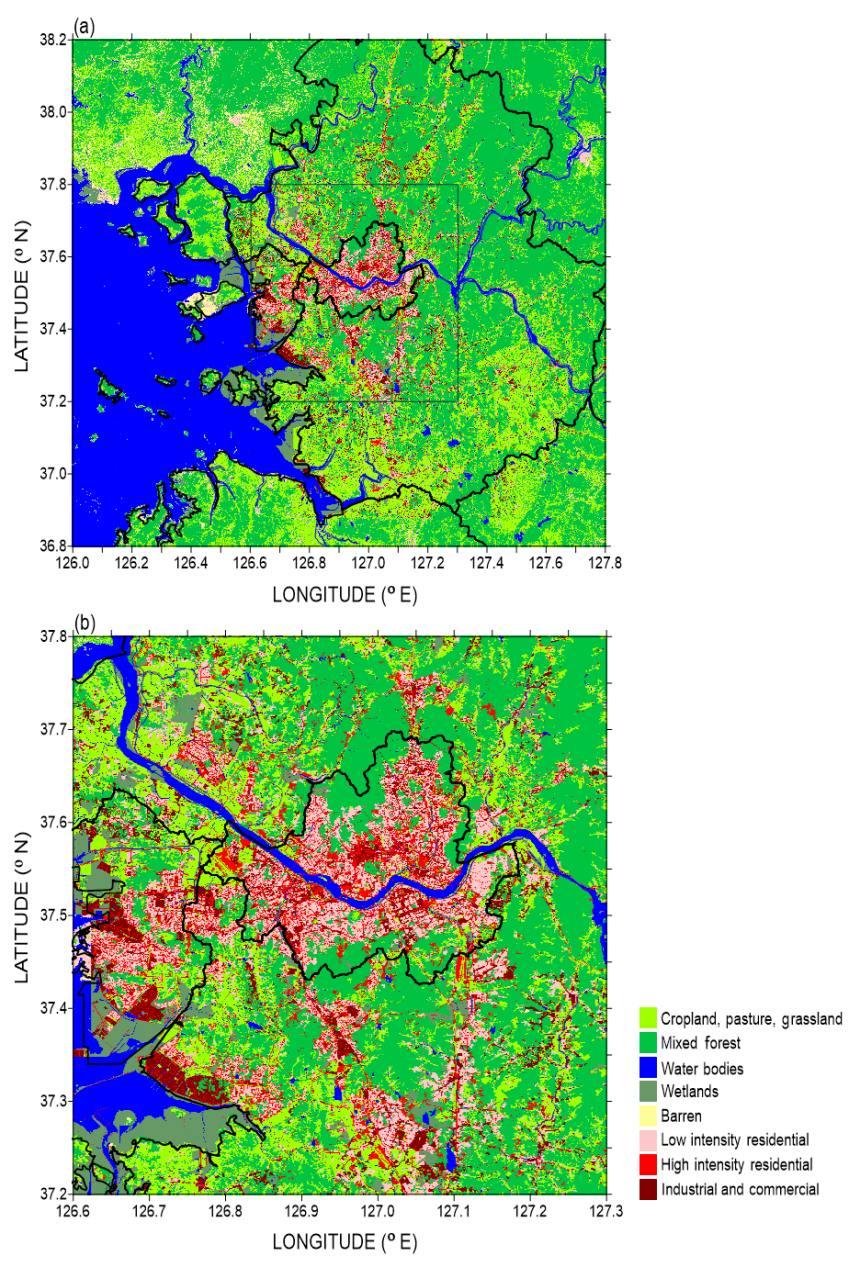

Figure 2. (a) Land use in the Seoul Metropolitan Area and (b) zoomed image of the highly populated region shown by the rectangle in panel (a).

\section{Background meteorological observation network}

Many background meteorological observation systems have already been installed in the SMA (Fig. 3; Table 3). There are over 110 meteorological observation stations operated by the Korea Meteorological Administration (KMA), whose locations are selected based on the administrative district, and more than 1000 meteorological observation stations operated by a subsidiary company of SK (largest telecommunication company in South Korea, SKP), whose locations are selected based on the daytime and resident populations in Domain 1. The KMA-operated automatic synoptic observation system (ASOS) observes the air pressure, evaporation, cloud amount, sunshine, snow depth, surface and ground temperatures, and weather phenomena and the basic meteorological variables of the grass surface with minimized obstacles. All ASOS stations follow the guidelines of the World Meteorological Organization (WMO, 2008). The KMA-operated automatic weather system (AWS) has a wind speed/direction
Table 2. Percentage of land use in the SMA domain (Domain 1) and highly populated domain (Domain 2).

\begin{tabular}{lrr}
\hline Land use & $\begin{array}{r}\text { Domain 1 } \\
(\%)\end{array}$ & $\begin{array}{r}\text { Domain 2 } \\
(\%)\end{array}$ \\
\hline Cropland, pasture, grassland & 21.5 & 20.6 \\
Forest & 41.9 & 36.0 \\
Water bodies & 20.9 & 6.4 \\
Wetlands & 5.0 & 8.6 \\
Barren & 2.1 & 0.1 \\
Urban (low-intensity residential) & 4.3 & 12.8 \\
Urban (high-intensity residential) & 2.2 & 9.0 \\
Urban (industrial and commercial) & 2.0 & 6.5 \\
\hline
\end{tabular}

sensor at 7 or $10 \mathrm{~m}$, a temperature sensor at $1.5-2 \mathrm{~m}$, precipitation detection, and a tipping-bucket-type rain gauge with heater, while each SKP-operated AWS has an integrated meteorological sensor and tipping-bucket-type rain gauge without heater, which is set to not measure precipitation in winter. Some of the KMA-operated AWSs and most SKP-operated meteorological stations are installed on the rooftops of buildings; few are installed in street canyons due to space restrictions. Regardless of the installation environment, if we choose any point with urban land cover in Seoul Special City, the distance from that point to the nearest AWS will be less than $1 \mathrm{~km}$.

There are two rawindsonde stations, two wind profiler and microwave radiometer stations, and six radar stations in Domain 1 (Fig. 3). The Osan (WMO station number 47122) and Baengnyeongdo (WMO station number 47102) stations observe the upper-air meteorological variables four and two times a day, respectively. A wind profiler and microwave radiometer are installed at the Paju and Cheorwon stations to observe the vertical profile of wind, temperature, and humidity. With respect to radar stations, KMA operates three Sband and one C-band radar, the Korea Institute of Civil Engineering and Building Technology operates one X-band radar, the South Korean Air Force operates one C-band radar, and the Ministry of Land, Infrastructure, and Transport operates one C-band radar in Domain 1 (Fig. 3).

Even though high-resolution and various meteorological observation systems are located in the SMA, there are still many unknowns regarding urban surface forcing and vertical profiles of temperature, humidity, and wind that impede our understanding of the fundamentals of urban meteorological phenomena in highly populated areas of the SMA. To counter this, the WISE project was designed and the UMS-Seoul was installed in this area. 

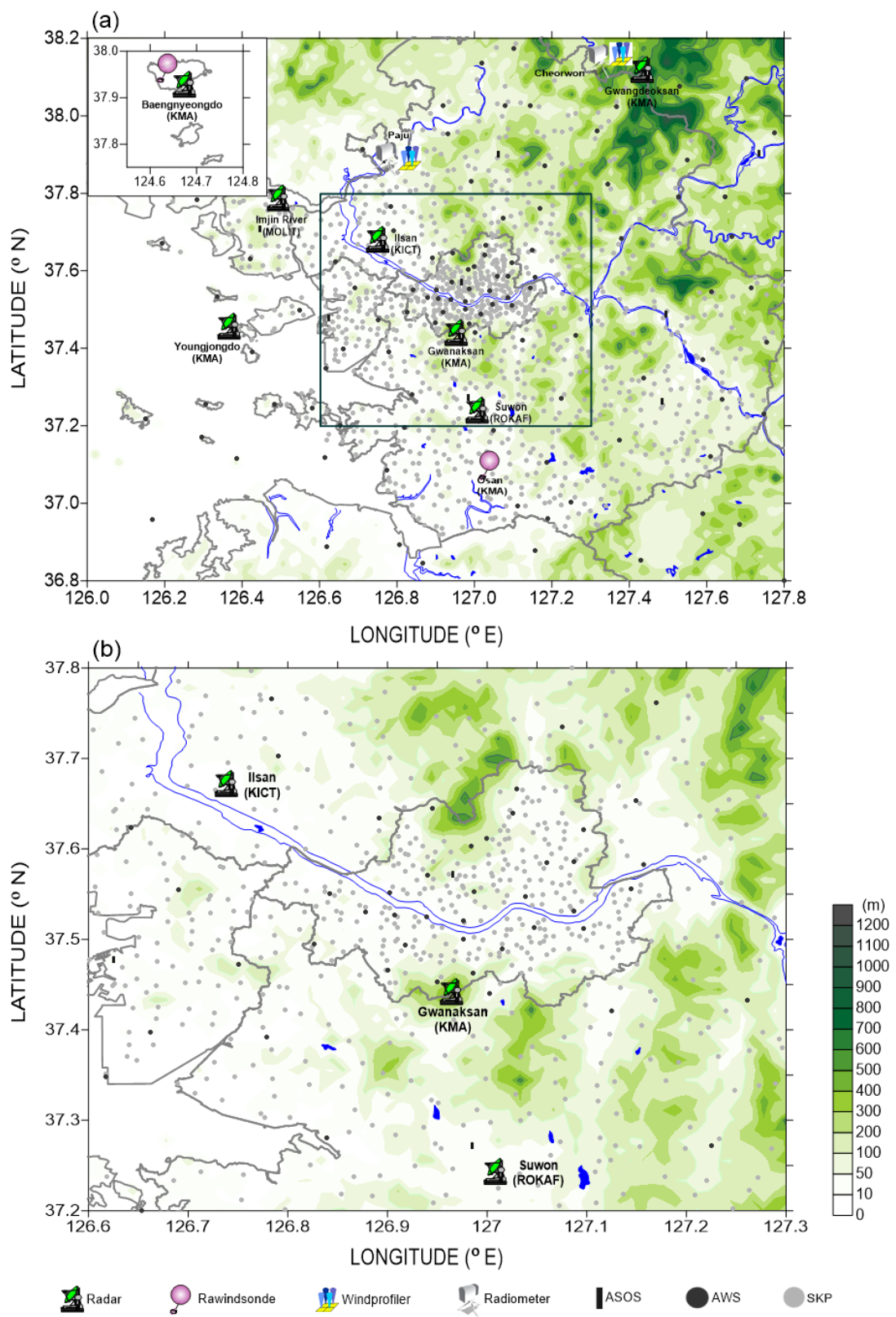

Figure 3. Location of background radars, rawindsondes, wind profilers, radiometers, automatic synoptic observation systems, automatic weather systems, and SKP automatic weather systems in the (a) Seoul Metropolitan Area and (b) highly populated region.

\section{Urban meteorological observation network system (UMS-Seoul) and its applications}

The UMS-Seoul is composed of a surface EB observation network, a 3-D meteorological observation network, an AP observation network, and the existing surface-based meteorological observation network in the SMA. Table 4 shows the simplified specifications and installed sensors in each observation network.

Figure 4 shows the location of each meteorological observation network station in UMS-Seoul. The locations are selected considering the surface land cover and horizontal distribution of geography and topography. Table 5 shows the land cover of the major observation stations classified by Auer (1978), Davenport et al. (2000), Oke (2004), and Stewart and Oke $(2009,2012)$. Each station represents a different type of land cover. The Yeouido and Gwangjin stations, located on the border of the Han River, are representative river sites. Typifying intensely developed and compact highrise sites, Gwanghwamun, Guro, and Songdo are located in the center of Seoul Special City, southwest of Seoul Special City, and south of Incheon Metropolitan City, respectively. 
Table 3. Specification and installed sensors of the existing meteorological observation network in the Seoul Metropolitan Area.

\begin{tabular}{|c|c|c|c|c|c|}
\hline Systems & \multicolumn{5}{|c|}{ Descriptions } \\
\hline $\begin{array}{l}\text { Automatic } \\
\text { synoptic } \\
\text { observation } \\
\text { system }\end{array}$ & $\begin{array}{l}\text { Operator } \\
\text { Number } \\
\text { Variable }\end{array}$ & \multicolumn{4}{|c|}{$\begin{array}{c}7 \\
\text { Temperature, relative humidity, wind speed, wind direction, solar } \\
\text { radiation, grass temperature, underground temperature, air pressure, } \\
\text { evaporation, sunshine, snow depth, precipitation, precipitation detection, } \\
\text { (manual) weather phenomena, cloud amount }\end{array}$} \\
\hline $\begin{array}{l}\text { Automatic } \\
\text { weather } \\
\text { system }\end{array}$ & $\begin{array}{l}\text { Operator } \\
\text { Number } \\
\text { Sensors }\end{array}$ & \multicolumn{4}{|c|}{$\begin{array}{l}\text { Korea Meteorological Administration } \\
\qquad 108 \\
\text { nperature, wind speed, wind direction, precipitation, } \\
\text { precipitation detection }\end{array}$} \\
\hline $\begin{array}{l}\text { Integrated } \\
\text { meteorological } \\
\text { observation } \\
\text { station }\end{array}$ & $\begin{array}{l}\text { Operator } \\
\text { Number } \\
\text { Sensors }\end{array}$ & \multicolumn{4}{|c|}{$\begin{array}{l}\text { SKP } \\
1078 \\
\text { nidity, wind speed, wind direction, } \\
\text { sure, precipitation }\end{array}$} \\
\hline Radar & $\begin{array}{l}\text { Number } \\
\text { Specifications }\end{array}$ & $\begin{array}{l}\text { Korea } \\
\text { Meteorological } \\
\text { Administration } \\
4 \\
\text { S-band 3; C-band } 1\end{array}$ & $\begin{array}{l}\text { Ministry of Land, } \\
\text { Infrastructure } \\
\text { and Transport } \\
1 \\
\text { C-band }\end{array}$ & $\begin{array}{l}\text { Korea Air } \\
\text { Force } \\
1 \\
\text { C-band }\end{array}$ & $\begin{array}{l}\text { Korea Institute } \\
\text { of Civil Engineering } \\
\text { and Building Technology } \\
1 \\
\text { X-band }\end{array}$ \\
\hline Wind profiler & $\begin{array}{l}\text { Operator } \\
\text { Number } \\
\text { Specifications }\end{array}$ & \multicolumn{4}{|c|}{$\begin{array}{l}\text { Korea Meteorological Administration } \\
2 \\
\text { UHF (ultra-high frequency) } 1.29 \mathrm{GHz}\end{array}$} \\
\hline Radiometer & $\begin{array}{l}\text { Operator } \\
\text { Number } \\
\text { Specification }\end{array}$ & \multicolumn{4}{|c|}{$\begin{array}{c}\text { Korea Meteorological Administration } \\
2 \\
\text { Humidity } 7 \text { channel }(22-30 \mathrm{GHz}) \text {; temperature } 7 \text { channel }(51-59 \mathrm{GHz})\end{array}$} \\
\hline Rawindsonde & $\begin{array}{l}\text { Operator } \\
\text { Number } \\
\text { Specification }\end{array}$ & \multicolumn{4}{|c|}{$\begin{array}{c}\text { Korea Meteorological Administration } \\
2 \\
00: 00,12: 00 \text { UTC for regular (06:00, 18:00 UTC option })\end{array}$} \\
\hline
\end{tabular}

The Songdo Station, in particular, is a newly developed highrise building complex. The Anyang and Nowon stations are surrounded by apartment building complexes, one of the typical residential types. The Jungnang, Gajwa, Gangnam, and Seongnam stations are located in old residential areas in the SMA. As rural stations, Youngin and Bucheon represent urban forest and crop field sites, respectively.

All 14 surface EB observation systems are deployed on the tower installed on the ground or on a rooftop of a building surrounded by similar surface land cover (residential, commercial, industrial, mixed, and rural). The measurement tower height ranges from $1.5 \mathrm{~m}$ (river side) to $18.5 \mathrm{~m}$ (Jungnang). Each system includes two or three temperature, relative humidity, wind speed, and wind direction sensors, one to three $\mathrm{CO}_{2} / \mathrm{H}_{2} \mathrm{O}$ infrared gas analyzers, two or three sonic anemometers, an air pressure sensor, a precipitation gauge with heater, one to three surface temperature sensors, and a four-component net radiometer (downward/upward and shortwave/longwave radiometers). Figure 5 shows a typical EB measurement tower, including sensors, representa- tive of surface land cover in the SMA. Manufacturer, model, measurement range, and accuracy of sensors are listed in Table 6. The CR3000 is used for data logging and LoggerNet for operating the software manufactured by Campbell Scientific, Inc. The performances of all meteorological sensors were certified by the manufacturer before shipping. In addition, most meteorological sensors were also certified by the Korea Meteorological Industry Promotion Agency before installation. Performance certificates have been issued and will be renewed every 3 years. The $\mathrm{H}_{2} \mathrm{O}$ and $\mathrm{CO}_{2}$ infrared gas analyzer is calibrated every 6 months according to the procedure suggested in the manual (https:// s.campbellsci.com/documents/af/manuals/ec150.pdf). Additionally, a large-aperture scintillometer (manufactured by Kipp \& Zonen, model MK-II) and six thermal infrared imagery systems (manufactured by Nippon Avionics, model TS9230) are installed to obtain the line-averaged sensible heat flux and sub-building-scale spatial distributions of the surface temperature, respectively. 
Table 4. Sensors installed in the surface energy balance system and specifications of instruments of the 3-D and applied meteorological observation system. The manufacturer and model name for each 3-D instrument and sensor used in the applied meteorological system are added.

\begin{tabular}{|c|c|c|}
\hline Systems & & Sensor or specification \\
\hline \multirow{5}{*}{$\begin{array}{l}\text { Surface energy } \\
\text { balance system }\end{array}$} & Sites & 14 (rural, residential, commercial, industrial, apartment, river) \\
\hline & Tower height & $4.0-18.5 \mathrm{~m}$ \\
\hline & Sensor & $\begin{array}{l}\text { Temperature, relative humidity, wind speed, wind direction, downward/upward or short- } \\
\text { wave/longwave radiation, } \mathrm{CO}_{2} / \mathrm{H}_{2} \mathrm{O} \text { infrared gas analyzer, sonic anemometer, surface tem- } \\
\text { perature, rain gauge, water temperature (two stations), thermal infrared imagery (Jungnang, } \\
\text { Gwanghwamun, Gajwa, Anyang, Guro - two sets) }\end{array}$ \\
\hline & $\begin{array}{l}\text { Temporal } \\
\text { resolution }\end{array}$ & $\begin{array}{l}1 \mathrm{~min} \text { for meteorological variables } \\
10 \mathrm{~Hz} \text { sampling and } 30 \mathrm{~min} \text { averaging for turbulent flux (sonic anemometer, } \mathrm{CO}_{2} / \mathrm{H}_{2} \mathrm{O} \text { gas an- } \\
\text { alyzer) }\end{array}$ \\
\hline & Option & $\begin{array}{l}\text { Large-aperture scintillometer (Kipp \& Zonen, MK-II) - one set } \\
\text { Surface temperature monitoring system - two sets }\end{array}$ \\
\hline \multirow[t]{4}{*}{$\begin{array}{l}\text { 3-D } \\
\text { meteorological } \\
\text { observation } \\
\text { system }\end{array}$} & $\begin{array}{l}\text { Ceilometer } \\
\text { (Vaisala, CL51) }\end{array}$ & $\begin{array}{l}\text { Two stations } \\
\text { Wavelength: } 910 \mathrm{~nm} \\
\text { Backscatter by aerosol (up to } 15 \mathrm{~km}, 10 \mathrm{~m} \text { vertical resolution); cloud base heights (three levels) } \\
\text { (1 min temporal resolution) } \\
\text { Accuracy: } \pm 5 \mathrm{~m} \text { for cloud base height }\end{array}$ \\
\hline & $\begin{array}{l}\text { Aerosol lidar } \\
\text { (Raymetrics, } \\
\text { LB210-D200) }\end{array}$ & $\begin{array}{l}\text { Two stations } \\
\text { Wavelength: } 532 \mathrm{~nm} \text { (parallel, cross-polarized), } 1064 \mathrm{~nm} \\
\text { Backscatter by aerosol (up to } 16 \mathrm{~km}, 3.75 \mathrm{~m} \text { vertical resolution), depolarization ratio, backscat- } \\
\text { tering coefficient ( } 2 \text { min temporal resolution, } 1 \mathrm{~h} \text { average) }\end{array}$ \\
\hline & $\begin{array}{l}\text { Microwave } \\
\text { radiometer } \\
\text { (RPG, } \\
\text { HATPRO-G4) }\end{array}$ & $\begin{array}{l}\text { Seven stations } \\
\text { Water vapor ( } 22-31 \mathrm{GHz}, 7 \text { channels), temperature ( } 51-58 \mathrm{GHz}, 7 \text { channels) } \\
\text { Atmospheric attenuation for each channel, vertical profile of temperature, humidity, liquid water } \\
\text { content ( } 1 \text { min temporal resolution) } \\
\text { Vertical resolution (m): } 30 \text { up to } 1200 \mathrm{~m}, 200 \text { up to } 5000 \mathrm{~m}, 400 \text { up to } 10000 \mathrm{~m} \text { for temperature } \\
\text { profile; } 200 \text { up to } 2000 \mathrm{~m}, 400 \text { up to } 5000 \mathrm{~m}, 800 \text { up to } 10000 \mathrm{~m} \text { for humidity profile } \\
\text { RMS accuracy: } 0.25 \mathrm{~K} \text { (up to } 500 \mathrm{~m} \text { ), } 0.50 \mathrm{~K} \text { (up to } 1200 \mathrm{~m} \text { ), } 0.75 \mathrm{~K} \text { (up to } 4000 \mathrm{~m} \text { ), } 1.00 \mathrm{~K} \text { (up } \\
\text { to } 10000 \mathrm{~m} \text { ) for temperature, } 5 \% \text { for relative humidity }\end{array}$ \\
\hline & $\begin{array}{l}\text { Wind lidar } \\
\text { (Leosphere, } \\
\text { Windcube-200) }\end{array}$ & $\begin{array}{l}\text { Six stations } \\
\text { Wavelength: } 1532 \mathrm{~nm} \\
\text { Wind speed and direction (up to } 6000 \mathrm{~m}, 100 \mathrm{~m} \text { vertical resolution) }(21 \mathrm{~s} \text { sample and } 10 \mathrm{~min} \\
\text { average) } \\
\text { RMS accuracy: } 0.3 \mathrm{~m} \mathrm{~s}^{-1} \text { for wind speed, } 1.5^{\circ} \text { for wind direction }\end{array}$ \\
\hline \multirow[t]{2}{*}{$\begin{array}{l}\text { Applied } \\
\text { meteorological } \\
\text { observation } \\
\text { system }\end{array}$} & Road & $\begin{array}{l}\text { Six stations/mobile road weather vehicle - one set } \\
\text { Fixed: wind speed and direction (RM Young, 05103), temperature and humidity (Vaisala, } \\
\text { HMP155), pressure (Vaisala, PTB110), precipitation (ELP, ERGH), precipitation detection } \\
\text { (ELP, ERD100), insolation (Kipp \& Zonen, CMP10), net radiometer (Kipp \& Zonen, CNR4), } \\
\text { road sensor (surface temperature and status, salinity, water depth) (Lufft, IRS31Pro) (1 min tem- } \\
\text { poral resolution) } \\
\text { Mobile: wind speed and direction (Vaisala, WMT703), temperature and humidity (Vaisala, } \\
\text { HMP155), pressure (Vaisala, PTB330), precipitation (Vaisala, RG13H), precipitation detec- } \\
\text { tion (Vaisala, DRD11A), insolation (Kipp \& Zonen, CMP11), net radiometer (Kipp \& Zonen, } \\
\text { CNR4), road sensor (surface temperature, status, salinity, and water depth) (Vaisala, DSP310), } \\
\text { global positioning system (TRIMBLE, NetR9) (1 s temporal resolution) }\end{array}$ \\
\hline & $\begin{array}{l}\text { Water quality } \\
\text { (HYDROLAB, } \\
\text { DS5X) }\end{array}$ & $\begin{array}{l}\text { Two stations } \\
\text { Water temperature, pH, conductivity, dissolved oxygen, salinity, turbidity, chlorophyll } a \text {, water } \\
\text { depth ( } 5 \text { min temporal resolution) }\end{array}$ \\
\hline
\end{tabular}


Table 4. Continued.

\begin{tabular}{ll}
\hline \multicolumn{1}{c}{ Systems } & \multicolumn{1}{c}{ Sensor or specification } \\
\hline $\begin{array}{l}\text { Mosquito } \\
\text { VER III) }\end{array}$ & $\begin{array}{l}\text { Three stations } \\
\text { Mosquito activity (1 h temporal resolution) }\end{array}$ \\
\cline { 2 - 3 } Greenhouse gas & $\begin{array}{l}\text { One station } \\
\text { CH4 concentration (LI-COR, LI-7700), total radiation (Kipp \& Zonen, CMP10), diffuse radi- } \\
\text { ation (Kipp \& Zonen, CMP10) with sun tracker (Kipp \& Zonen, SOLYS2) (30 min temporal } \\
\text { resolution) }\end{array}$ \\
\hline Agrometeorology & $\begin{array}{l}\text { Four stations } \\
\text { Net radiometer (Kipp \& Zonen, CNR4), temperature and humidity (Vaisala, HMP155A), albedo } \\
\text { (Kipp \& Zonen, CMA6), leaf wetness (Campbell, LWS), soil moisture content (Campbell, } \\
\text { CS616), wind speed and direction (RM Young, 05103), precipitation (Wedaen, WDR-202), } \\
\text { soil temperature (Campbell, 107), ground heat flux (Hukseflux, HFP01), Quantum (LI-COR, } \\
\text { LI190SB) (1 min temporal resolution) }\end{array}$ \\
\hline
\end{tabular}

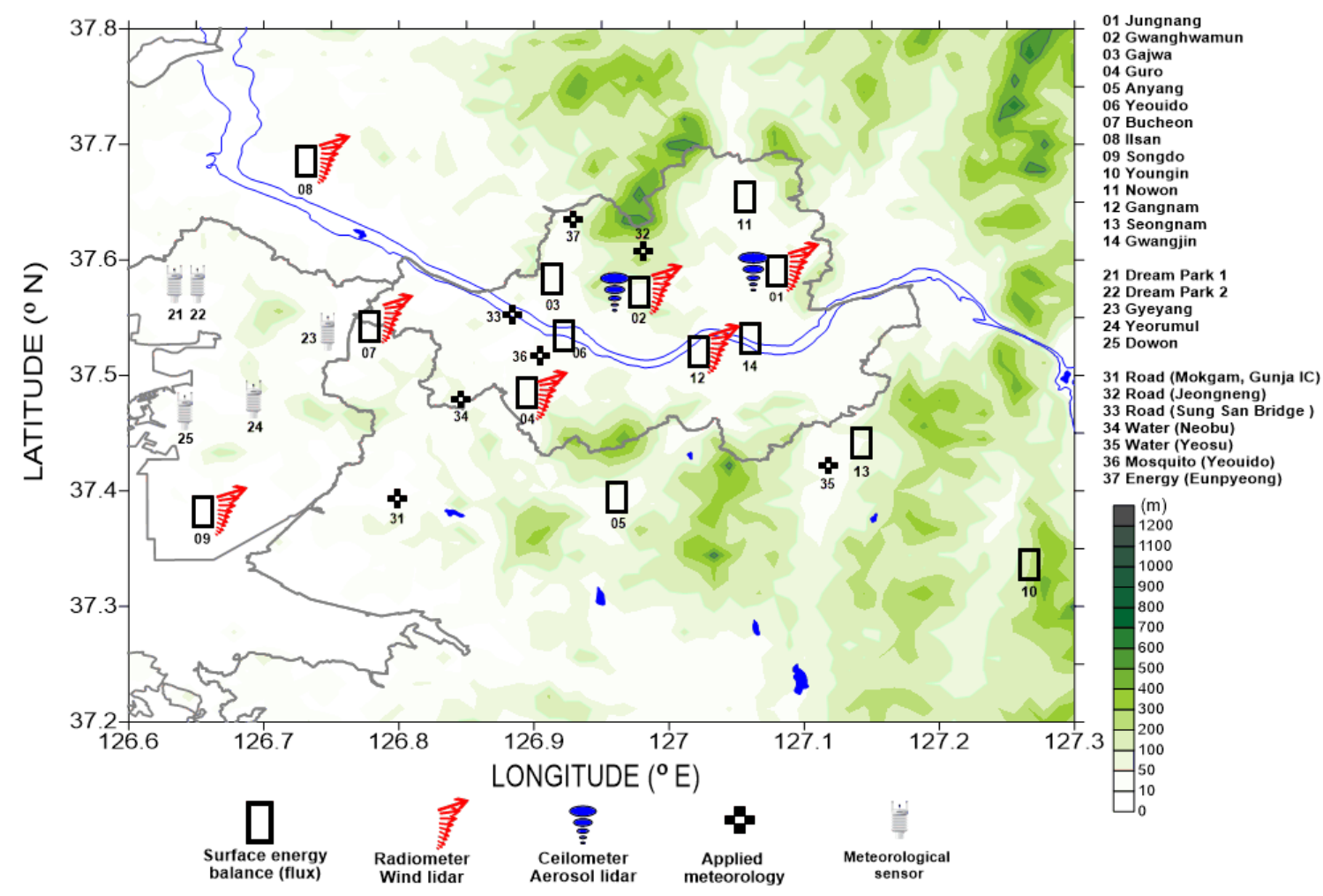

Figure 4. Location of the UMS-Seoul urban meteorological observation system networks in the highly populated region of the Seoul Metropolitan Area.

Quality check algorithms for meteorological variables and flux data have previously been developed (Aubinet et al., 2012; Chae et al., 2014; M.-S. Park et al., 2013, 2014a; Kim et al., 2015). Basic quality checks for meteorological variables include missing check, physical limit check, climate range check, and spike removal (Chae et al., 2014). Surface fluxes are computed from $10 \mathrm{~Hz}$ raw data using the following procedure: (1) physical limit check, (2) detection and removal of spike data (Vickers and Mahrt, 1997), (3) computation of the vertical flux with a 30 min block average (Kwon et al., 2014), and (4) Webb-Pearman-Leuning correction (Webb et al., 1980; Leuning, 2007).

The EB systems, installed on different land cover in urban areas, are applied to determine not only the surface EB among the net radiation, sensible heat flux, latent heat flux, heat storage or ground heat flux, and anthropogenic heat flux 
Table 5. Land cover classification of major observation stations.

\begin{tabular}{lrr|lllll}
\hline & \multicolumn{2}{l}{ Station } & & & \multicolumn{2}{c}{ Classification } \\
\hline Name & $\begin{array}{r}\text { Building } \\
\text { height }(\mathrm{m})\end{array}$ & $\begin{array}{r}\text { Tower } \\
\text { height }(\mathrm{m})\end{array}$ & $\begin{array}{l}\text { Auer } \\
(1978)^{\mathrm{a}}\end{array}$ & $\begin{array}{l}\text { Davenport et } \\
\text { al. (2000) }\end{array}$ & $\begin{array}{l}\text { Oke } \\
(2004)^{\mathrm{c}}\end{array}$ & $\begin{array}{l}\text { Stewart and } \\
\text { Oke (2009) }\end{array}$ & $\begin{array}{l}\text { Stewart and } \\
\text { Oke (2012) }\end{array}$ \\
\hline Jungnang & 23.0 & 18.5 & R2 & N7 E7 S7 W7 & UCZ-2 & Compact housing & LCZ-2E \\
Gwanghwamun & 71.0 & 7.0 & C1 & N8 E8 S8 W8 & UCZ-1 & Modern core & LCZ-1E \\
Gajwa & 23.0 & 10.0 & R2 & N7 E7 S7 W7 & UCZ-3 & Compact housing & LCZ-3E \\
Guro & 57.6 & 10.0 & C1 & N8 E8 S7 W6 & UCZ-1 & Modern core & LCZ-1E \\
Anyang & 63.5 & 10.0 & R1 & N7 E7 S7 W7 & UCZ-3 & Blocks & LCZ-4B \\
Yeouido & 12.0 & 6.5 & A5 & N1 E1 S7 W1 & UCZ-6 & Open ground & LCZ-4G \\
Bucheon & 0.0 & 15.0 & A2 & N3 E4 S3 W3 & UCZ-7 & Cropped fields & LCZ-9D \\
Ilsan & 4.0 & 10.0 & A2 & N5 E4 S4 W4 & UCZ-7 & Cropped fields & LCZ-9D \\
Songdo & 14.3 & 7.0 & C1 & N6 E6 S6 W6 & UCZ-7 & Modern core & LCZ-4E \\
Youngin & 0.0 & 15.0 & A1 & N7 E7 S7 W7 & UCZ-6 & Forest & LCZ-9A \\
Nowon & 37.5 & 10.0 & R1 & N5 E5 S5 W5 & UCZ-3 & Blocks & LCZ-4B \\
Gangnam & 21.2 & 4.0 & R2 & N7 E7 S8 W7 & UCZ-3 & Compact housing & LCZ-3E \\
Seongnam & 8.0 & 6.0 & R2 & N7 E7 S7 W7 & UCZ-3 & Compact housing & LCZ-3E \\
Gwangjin & 0.0 & 10.0 & A5 & N7 E1 S1 W1 & UCZ-6 & Open ground & LCZ-4G \\
\hline
\end{tabular}

a Auer (1978): A1, metropolitan natural; A2, agricultural rural; A5, water surfaces; C1, commercial; R1, common residential; R2, compact residential.

${ }^{\mathrm{b}}$ Davenport et al. (2000): N, north; E, east; S, south; W, west; 1 , sea; 3 , open; 4 , roughly open; 5 , rough; 6 , very rough; 7 , skimming; 8 , chaotic.

${ }^{c}$ Oke (2004) urban climate zones (UCZ): UCZ-1 intensely developed; UCZ-2 intensely developed high density; UCZ-3 highly developed medium density:

UCZ-6 mixed use with large buildings in open landscape; UCZ-7 semi-rural development with scattered houses.

d Stewart and Oke (2012) local climate zones (LCZ): 1, compact high-rise; 2, compact mid-rise; 3, compact low-rise; 4, open high-rise; 9, sparsely built; A, dense trees; B, scattered trees; C, bush scrub; D, low plant; E, bare rock or paved; G, water.

but also the surface thermal, optical, and physical properties such as thermal conductivity, heat capacity, albedo, emissivity, roughness length, and displacement length. The surface thermal conductivity, heat capacity, and emissivity are estimated and verified by comparison with the surface temperature determined based on the EB and heat transfer models with observed surface temperature (Monteith and Unsworth, 1990; Santillan-Soto et al., 2015). The surface roughness and displacement lengths are obtained by a micrometeorological method and verified with those obtained from urban morphology data such as mean building height, frontal area density, and plane area density from the geographical information system (Macdonald et al., 1998; Kwon et al., 2014). They are expected to produce high-resolution surface property maps, such as albedo, emissivity, and thermal conductivity, and surface roughness length and displacement (Yi et al., 2015; Jee et al., 2016). Furthermore, they determine the 30 min averaged carbon dioxide concentration and flux and the sensible heat flux, latent heat flux, radiative flux, and heat storage. The EB data are applied to verify the urban surface processes based on the land use and to improve the urban surface processes in meteorological models.

The 3-D meteorological observation network provides the real-time vertical profile of backscatter, wind speed and direction, temperature, and humidity using two aerosol lidars (manufactured by Raymetrics, model LB210-D200), two ceilometers (manufactured by Vaisala, model CL51), six wind lidars (three are manufactured by Leosphere, Windcube-200; three are manufactured by Laser Systems,
Windex-2000), and seven microwave radiometers (manufactured by RPG, HATPRO-G4; Table 5). The aerosol lidar provides the vertical distribution of the aerosols and aerosol optical depth using the vertical profile of the range-corrected backscatter signal and depolarization ratio from 532 and $1064 \mathrm{~nm}$ wavelength lasers. The ceilometer provides three levels of cloud base height and the vertical distribution of two-way attenuated backscatter from a $910 \mathrm{~nm}$ wavelength laser. The wind lidar provides the vertical profile of the wind speed and direction using the Doppler beam swinging scanning technology of a $1532 \mathrm{~nm}$ wavelength laser (Werner, 2005). The microwave radiometer provides the vertical profile of the temperature and humidity using the observed atmospheric attenuation of 14 wavelength channels. Each instrument except for the microwave radiometer has a vertical resolution of less than or equal to $50 \mathrm{~m}$ and a temporal resolution of less than $10 \mathrm{~min}$ : the aerosol lidar has a $3.75 \mathrm{~m}$ vertical resolution up to $16 \mathrm{~km}$ and 2 min temporal resolution; the ceilometer has a $10 \mathrm{~m}$ vertical resolution up to $15 \mathrm{~km}$ and 1 min temporal resolution; the microwave radiometer has a dense vertical resolution at low altitude but a coarse resolution at high altitude $(30 \mathrm{~m}$ up to $1.2 \mathrm{~km}, 200 \mathrm{~m}$ up to $5 \mathrm{~km}$, $400 \mathrm{~m}$ up to $10 \mathrm{~km}$ for temperature profile; $200 \mathrm{~m}$ up to $2 \mathrm{~km}$, $400 \mathrm{~m}$ up to $5 \mathrm{~km}, 800 \mathrm{~m}$ up to $10 \mathrm{~km}$ for relative humidity profile) and $1 \mathrm{~min}$ temporal resolution; and the wind lidar has a $50 \mathrm{~m}$ vertical resolution and a $10 \mathrm{~min}$ temporal resolution. The accuracy and reproducibility of each surface-based remote sensing instrument are also certified by the manufacturers before shipping. The vertical profiles obtained with 
Table 6. Manufacturer, model, measurement range, and accuracy or sensitivity of sensors deployed in the surface energy balance system.

\begin{tabular}{|c|c|c|c|}
\hline Sensor & $\begin{array}{l}\text { Manufacturer } \\
\text { (model) }\end{array}$ & Measurement range & Accuracy \\
\hline 3-D sonic anemometer & $\begin{array}{l}\mathrm{CSI}^{*} \\
(\mathrm{CSAT} 3 \mathrm{~B})\end{array}$ & $\begin{array}{l}u \& v: \pm 60 \mathrm{~ms}^{-1}, w: \pm 8 \mathrm{~ms}^{-1} \\
T_{\mathrm{s}}:-50-60^{\circ} \mathrm{C}\end{array}$ & $\begin{array}{l}u \& v< \pm 0.08 \mathrm{~m} \mathrm{~s}^{-1} \\
w< \pm 0.04 \mathrm{~m} \mathrm{~s}^{-1}\end{array}$ \\
\hline $\begin{array}{l}\mathrm{CO}_{2} \text { and } \mathrm{H}_{2} \mathrm{O} \text { open- } \\
\text { path gas analyzer and } \\
3-\mathrm{D} \text { sonic anemometer }\end{array}$ & $\begin{array}{l}\text { CSI/LI-COR } \\
(\text { EC150/ } \\
\text { CSAT3A) }\end{array}$ & $\begin{array}{l}\mathrm{CO}_{2}: 0-1798 \mathrm{mg} \mathrm{m}^{-3} \text { at } 25^{\circ} \mathrm{C}, 1 \mathrm{~atm} \\
\mathrm{H}_{2} \mathrm{O}: 0-52.9 \mathrm{~g} \mathrm{~m}^{-3} \text { at } 25^{\circ} \mathrm{C}, 1 \mathrm{~atm} \\
\text { 3-D sonic anemometer } u \& v: \pm 60 \mathrm{~m} \mathrm{~s}^{-1} \text {, } \\
w: \pm 8 \mathrm{~m} \mathrm{~s}^{-1}, T_{\mathrm{s}}:-50-60^{\circ} \mathrm{C}\end{array}$ & $\begin{array}{l}\mathrm{CO}_{2} \text { precision (RMS): } 0.2 \mathrm{mg} \mathrm{m}^{-3} \\
\text { Zero drift: } \pm 0.55 \mathrm{mg} \mathrm{m}-3{ }^{\circ} \mathrm{C}^{-1} \\
\text { Gain drift: } \pm 0.1 \% \text { of reading }{ }^{\circ} \mathrm{C}^{-1} \\
\mathrm{H}_{2} \mathrm{O} \text { precision (RMS): } 0.004 \mathrm{~g} \mathrm{~m}^{-3} \\
\text { Zero drift: } \pm 0.037 \mathrm{~g} \mathrm{~m}^{-3}{ }^{\circ} \mathrm{C}^{-1} \\
\text { Gain drift: } \pm 0.3 \% \text { of reading }{ }^{\circ} \mathrm{C}^{-1} \\
\text { 3-D sonic anemometer } \\
u \& v< \pm 0.08 \mathrm{~m} \mathrm{~s}^{-1}, w< \pm 0.04 \mathrm{~m} \mathrm{~s}^{-1}\end{array}$ \\
\hline Net radiometer & $\begin{array}{l}\text { Kipp \& } \\
\text { Zonen } \\
(\text { CNR4) }\end{array}$ & $\begin{array}{l}\text { Maximum irradiance: } 4000 \mathrm{~W} \mathrm{~m}^{-2} \\
\text { (shortwave); } 2000 \mathrm{~W} \mathrm{~m}^{-2} \text { (longwave) } \\
\text { Spectral range: } 300-2800 \mathrm{~nm} \text { (shortwave); } \\
4500-42000 \mathrm{~nm} \text { (longwave) }\end{array}$ & $\begin{array}{l}\text { Expected daily uncertainly: }<2 \% \text { (shortwave); } \\
<10 \% \text { (longwave) } \\
\text { Sensitivity: } 7-20 \mu \mathrm{V} \mathrm{W}^{-1} \mathrm{~m}^{2} \text { (shortwave); 5- } \\
10 \mu \mathrm{VW}^{-1} \mathrm{~m}^{2} \text { (longwave) }\end{array}$ \\
\hline $\begin{array}{l}\text { Temperature and } \\
\text { relative humidity probe }\end{array}$ & $\begin{array}{l}\text { CSI/Vaisala } \\
\text { (HMP155A) }\end{array}$ & $\begin{array}{l}\text { Temperature: }-80-60{ }^{\circ} \mathrm{C} \\
\text { Relative humidity: } 0-100 \%\end{array}$ & $\begin{array}{l}\text { Temperature: } \pm 0.3^{\circ} \mathrm{C} \\
\text { Relative humidity: } \pm 1 \% \text { at } 15-25^{\circ} \mathrm{C}, 0-90 \% \text {, } \\
\pm 1.7 \% \text { at } 15-25^{\circ} \mathrm{C}, 90-100 \%\end{array}$ \\
\hline Wind vane & $\begin{array}{l}\text { Vector } \\
\text { Instruments }\end{array}$ & $0-360^{\circ}$ & $\pm 3^{\circ}$ \\
\hline Three-cup anemometer & $\begin{array}{l}(\mathrm{W} 300 \mathrm{P} / \\
\mathrm{A} 100 \mathrm{M})\end{array}$ & $0-75 \mathrm{~m} \mathrm{~s}^{-1}$ & $\begin{array}{l}0.1 \mathrm{~m} \mathrm{~s}^{-1} \text { at } 0.1-10 \mathrm{~m} \mathrm{~s}^{-1} ; 1 \% \text { at } 10-55 \mathrm{~m} \mathrm{~s}^{-1} ; \\
2 \% \text { at } 55-75 \mathrm{~m} \mathrm{~s}^{-1}\end{array}$ \\
\hline Barometric pressure & $\begin{array}{l}\text { CSI/Vaisala } \\
\text { (CS106) }\end{array}$ & $500-1100 \mathrm{hPa}$ & $\begin{array}{l} \pm 0.3 \mathrm{hPa} \text { at } 20^{\circ} \mathrm{C} ; \pm 0.6 \mathrm{hPa} \text { at } 0-40{ }^{\circ} \mathrm{C} ; \\
\pm 1.0 \mathrm{hPa} \text { at }-20-45^{\circ} \mathrm{C}\end{array}$ \\
\hline $\begin{array}{l}\text { Infrared surface } \\
\text { temperature }\end{array}$ & $\begin{array}{l}\text { CSI/Apogee } \\
(\mathrm{SI}-111)\end{array}$ & $-40-70{ }^{\circ} \mathrm{C}$ & $\pm 0.5^{\circ} \mathrm{C}$ at $-40-70^{\circ} \mathrm{C}$ \\
\hline Precipitation gauge & $\begin{array}{l}\text { Wedaen } \\
\text { (WDSA-205) }\end{array}$ & $0.5 \mathrm{~mm}$ per $1 \mathrm{tip}$ & $\pm 3 \mathrm{~mm}$ at $150 \mathrm{~mm} \mathrm{~h}^{-1}$ \\
\hline Soil heat flux plate & $\begin{array}{l}\text { CSI/Hukseflux } \\
\text { (HFP01) }\end{array}$ & $-2000-2000 \mathrm{~W} \mathrm{~m}^{-2}$ & $\begin{array}{l}\text { Sensitivity: } 50 \mu \mathrm{V} \mathrm{W}^{-1} \mathrm{~m}^{2} \\
-15-5 \% \text { in most common soil }\end{array}$ \\
\hline Soil water content & $\begin{array}{l}\text { CSI } \\
(\mathrm{CS} 655)\end{array}$ & $\begin{array}{l}\text { Soil temperature: }-10-70^{\circ} \mathrm{C} \\
\text { Volumetric water content: } 5-50 \%\end{array}$ & $\begin{array}{l}\text { Soil temperature: } \pm 0.5^{\circ} \mathrm{C} \\
\text { Volumetric water content: } \pm 3 \%\end{array}$ \\
\hline $\begin{array}{l}\text { Soil and water } \\
\text { temperature }\end{array}$ & CSI (107) & $-35-50{ }^{\circ} \mathrm{C}$ & $\pm 1.0^{\circ} \mathrm{C}$ \\
\hline $\begin{array}{l}\text { Propeller-type wind } \\
\text { vane }\end{array}$ & $\begin{array}{l}\text { RM Young } \\
(05103)\end{array}$ & $\begin{array}{l}\text { Wind speed: } 0-100 \mathrm{~m} \mathrm{~s}^{-1} \\
\text { Wind direction: } 0-360^{\circ}\end{array}$ & $\begin{array}{l}\text { Wind speed: } \pm 0.3 \mathrm{~m} \mathrm{~s}^{-1} \\
\text { Wind direction: } \pm 3^{\circ}\end{array}$ \\
\hline $\begin{array}{l}\text { Thermal infrared } \\
\text { imagery }\end{array}$ & $\begin{array}{l}\text { Nippon } \\
\text { Avionics } \\
\text { (TS9230) }\end{array}$ & $\begin{array}{l}\text { Spectral range: } 8-14 \mu \mathrm{m} \\
\text { Pixel: } 320 \times 240 \\
\text { Field of view: } 21.7^{\circ} \times 16.4^{\circ}\end{array}$ & \\
\hline
\end{tabular}

* CSI: Campbell Scientific, Inc.

these instruments are compared with boundary-layer structures obtained from the sonde before installation or during the intensive sonde observation campaign period.

The mixing-layer height is determined as the height with a minimum gradient of attenuated backscatter or range- corrected backscatter obtained by a ceilometer or an aerosol lidar (Eresmaa et al., 2006) or based on the steepest decrease of the wind speed variance obtained with a wind lidar (Emeis et al., 2008). These instruments are expected to improve the knowledge about the effects of high-rise buildings and imper- 


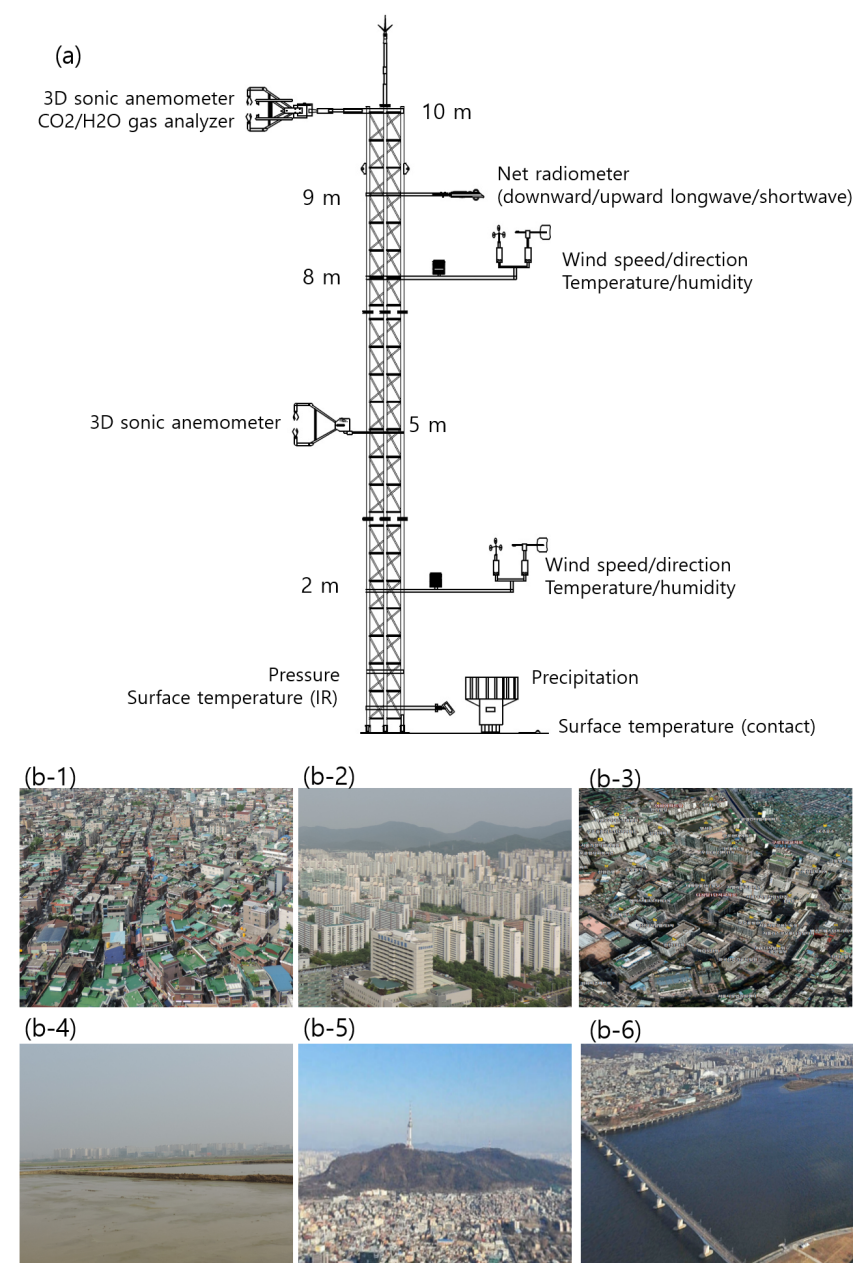

Figure 5. (a) Sensor deployment of a typical surface energy balance system and representative surface covers of (b-1) residential, (b-2) apartment, (b-3) industrial area, (b-4) urban rice paddy, (b5) forest, and (b-6) river areas.

vious and manmade material on urban boundary-layer structures and to eventually produce observation-based 3-D meteorological fields with high quality and high resolution by combination with meteorological model results.

The AP observation system includes road weather, water quality, mosquito, and agrometeorology information systems. Each AP system is designed to support each applied purpose through the verification and improvement of each service-capable model. For example, the Road Weather Information System (RWIS) observed the road surface temperature and status, water depth, salinity, and conductivity and net radiation, temperature, humidity, wind speed, and wind direction on an open road in 2013, at the entrance and exit of a tunnel in 2014, and on a complex road structure with a bridge and joint cross section in 2015. These data will be used to verify and improve the road surface temperature, status, and braking distance prediction model (Yang et al., 2011; Park et al., 2014b). A mobile road weather vehicle equipped with a global positioning system and sensors in RWIS is operated to find the road sections vulnerable to road wetness and ice. The water quality information system observes the turbidity, salinity, conductivity of stream water, dissolved oxygen, and biological oxygen demand to support the water quality information service. The mosquito activity information system observes the number of mosquitoes and meteorological variables for the purpose of a mosquito advisory and warning service. The agrometeorological information system observes the soil moisture and temperature, ground heat flux, evaporation, leaf wetness, and leaf temperature, as well as basic meteorological variables, including sensible and latent heat fluxes, to predict the productivity of crops.

\section{Case studies}

To demonstrate the usefulness of UMS-Seoul and applicability to the meteorological information service customized user demands, two case studies are conducted: (1) to determine the spatial distribution of meteorological surface variables and evolution of urban boundary-layer structures during 3 consecutive days in spring; (2) to find the road sections vulnerable to road ice using the surface temperature and status on a roadway obtained with a mobile road weather vehicle.

\subsection{Case study I: spring zonal anticyclone event}

Meteorological surface variables and atmospheric boundarylayer structures are investigated for the period from 18 to 20 May 2016. During this period, a zonal anticyclone in northern Japan blocks an eastward-moving weather system; the weather system is stagnant. As a result, the SMA indicates fine weather at the edge of a high-pressure system. A short-lived and small thermal low-pressure system driven by the thermal difference between the continent and sea develops in the afternoon and disappears in the evening on 19 and 20 May 2016.

Figure 6 shows the horizontal distribution of the air temperature obtained by the SKP surface meteorological observation system at 06:00, 12:00, 18:00, and 24:00 LST on 18 May 2016. The temperature is corrected according to the sea-level height of the sensor using the monthly mean lapse rate $\left(4.8 \mathrm{~K} \mathrm{~km}^{-1}\right)$ of the free atmosphere observed by a rawindsonde at the Osan Station (Fig. 3; Park et al., 2014a). At 06:00 and 24:00 LST, the western sites show a relatively high temperature when there is no surface heating, while the eastern sites show a relatively low temperature. In contrast, at 12:00 and 18:00 LST, the eastern sites show a relatively high temperature, while the western sites show a relatively low temperature. The urban area shows higher temperatures than the surrounding region throughout this period, which is mainly due to the heat capacity difference between the urban and rural regions and anthropogenic heat release. The temperature difference between the two land covers, that is, the 

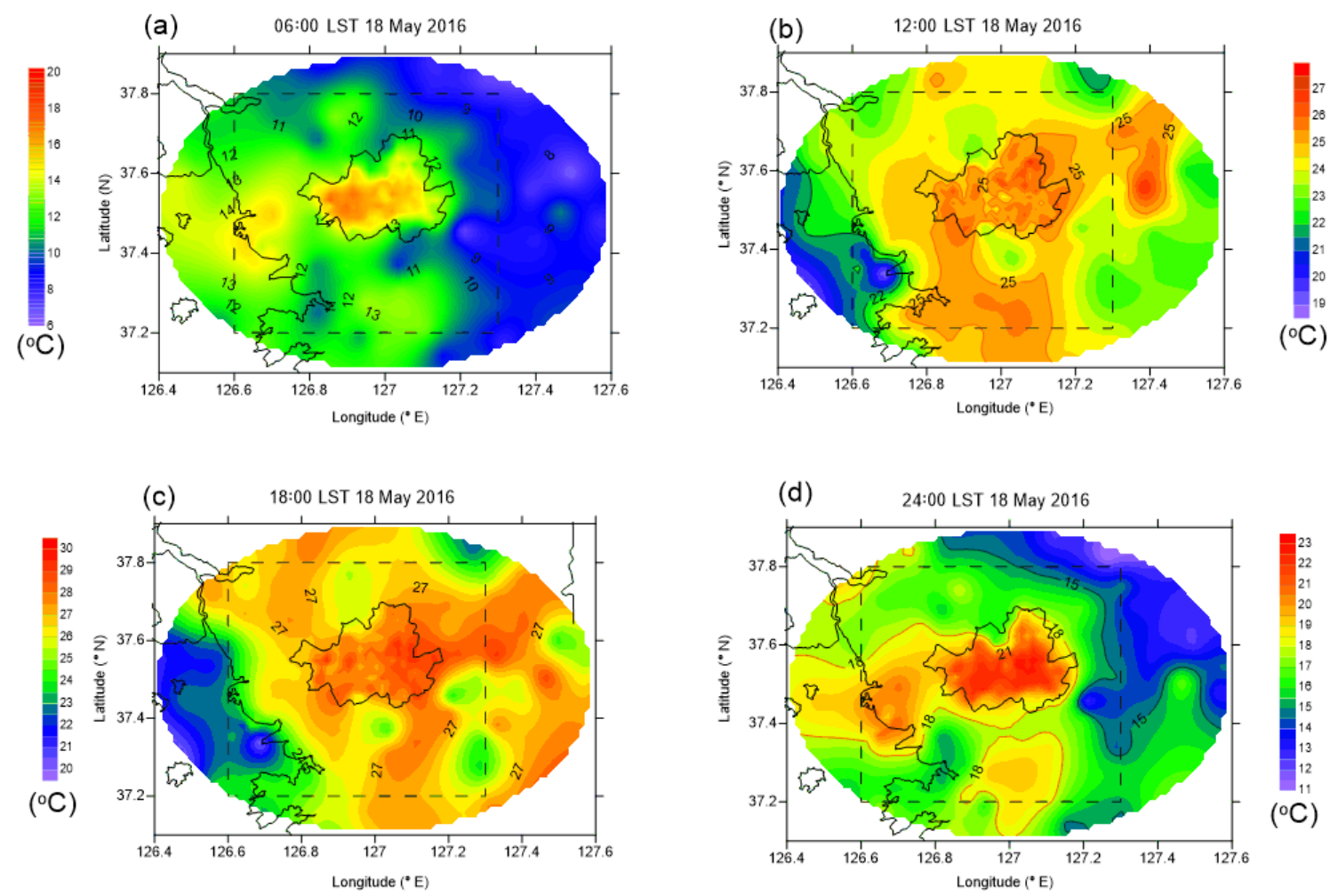

Figure 6. Horizontal distribution of the air temperature obtained with the SKP surface meteorological observation system at (a) 06:00 LST, (b) 12:00 LST, (c) 18:00 LST, and (d) 24:00 LST on 18 May 2016, in the Seoul Metropolitan Area. The dotted rectangle denotes the highly populated region in Fig. $1 \mathrm{~b}$.

urban heat island effect, becomes stronger during the night (Khan and Simpson, 2001; Freitas et al., 2007; Ryu and Baik, 2013). These temperature differences imply the possibility of local circulation such as land-sea breeze and urban-rural circulation.

Figure 7 shows the time series of surface meteorological variables obtained every minute by a surface EB system installed at the Jungnang Station (Fig. 4) for the period from 00:00 LST on 18 May to 24:00 LST on 20 May 2016. During this period, it was so clear that the daily cloud cover was recorded as 5, 0 , and $6 \%$ on 18,19 , and 20 May 2016, respectively. The air pressure minimum occurred at $\sim 15: 00$ 18:00 LST every day, accompanied by a wind speed, direction, and vapor pressure change (Fig. 7a, b, d, and e). That is to say, after the low air pressure passed the station, the wind direction abruptly changed to northwesterly, the air temperature dropped down by $1.8^{\circ} \mathrm{C}\left(3.5^{\circ} \mathrm{C}\right)$, and the vapor pressure jumped up by $2.6 \mathrm{hPa}(8.0 \mathrm{hPa})$ on 19 (20) May. The diurnal variation of the wind speed and direction shows that the station is affected by local circulations: northeasterly winds are dominant at night, while other directional winds are dominant during the day (Fig. 7c and d). The net radiation is negative at night and positive during the day; the variation indicates that there are few clouds during this period, except for the afternoon of 20 May (Fig. 7f).
Figure 8 shows the backscattering coefficient observed by a ceilometer and vertical profile of the wind observed by a wind lidar at the Jungnang Station for the period from 00:00 LST on 18 May to 24:00 LST on 20 May 2016. The atmospheric boundary-layer structures defined by the attenuated backscatter profile perfectly coincide with those defined by the wind: (1) the attenuated backscatter shows that there are two distinct layers before 10:00 LST on 18 May; the lower layer with a maximum height of $400 \mathrm{~m}$ contains thick backscattering aerosols, while the upper layer is less dense up to $1.2 \mathrm{~km}$. The wind profile also shows that the two layers have different origins: easterly winds are dominant in the lower layer, while westerly winds are dominant in the upper layer. (2) The convective atmospheric boundary layer defined by attenuated backscatter evolves during the day on 3 consecutive days. Correspondingly, the winds become irregular in the same layer. (3) The residual layer with a high attenuated backscatter at $\sim 2 \mathrm{~km}$ at night moves slowly downward until the next morning and combines with the evolving convective boundary layer at noon on 19 May. Southerly winds are in the upper residual layer, while northerly or northeasterly winds are in the lower stable boundary layer; the highly attenuated backscatter zones from 500 to $1500 \mathrm{~m}$ at 03:0009:00 LST and $>1000 \mathrm{~m}$ at $\sim$ 18:00 LST on 20 May correspond to the wind convergence zone. The potential temper- 
(a)

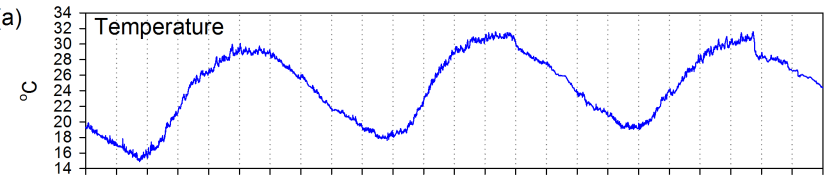

(b)

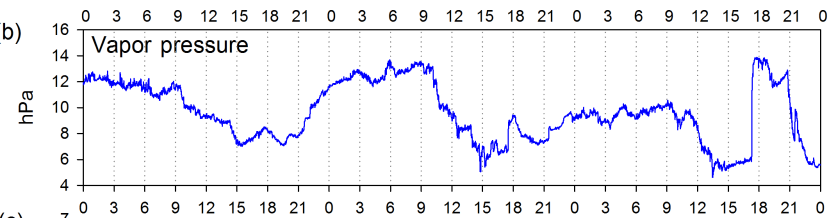

(c)

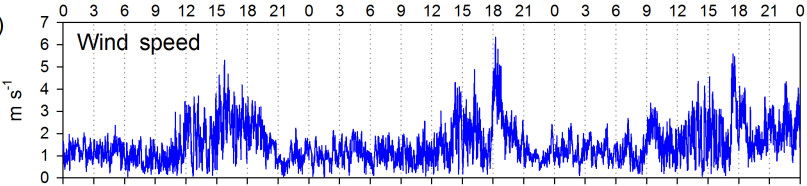

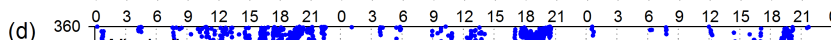

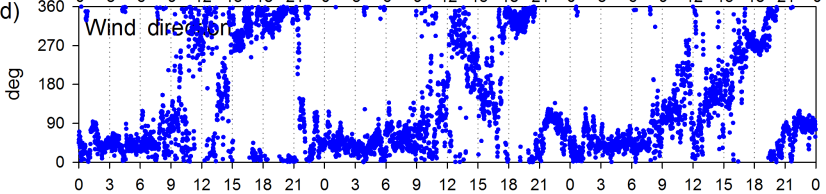

(e) 1017 Air pressure

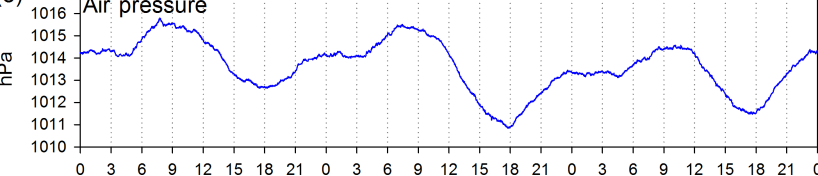

(f) $800 \begin{array}{lllllllllllllllllllllllll}0 & 3 & 6 & 9 & 12 & 15 & 18 & 21 & 0 & 3 & 6 & 9 & 12 & 15 & 18 & 21 & 0 & 3 & 6 & 9 & 12 & 15 & 18 & 21 & 0\end{array}$

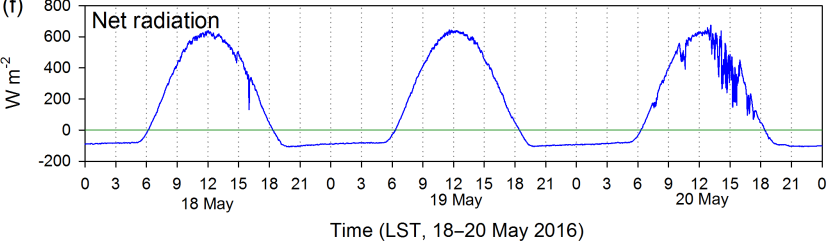

Figure 7. Time series of the (a) air temperature, (b) vapor pressure, (c) wind speed, (d) wind direction, (e) air pressure, and (f) net radiation observed at the Jungnang Station from 18 to 20 May 2016.

ature and mixing ratio profiles obtained by the microwave radiometer also support the similar atmospheric boundarylayer structures (Fig. 9). In conclusion, the meteorological surface variables and vertical profiles of the meteorological variables observed with UMS-Seoul will be very helpful to produce a high-quality and high-resolution meteorological field in the SMA.

\subsection{Case study II: mobile road weather vehicle}

Figure 10 shows an example of road surface temperature on a roadway route in the Seoul Metropolitan Area observed by a mobile road weather vehicle with road material, structure, and elevation for the period from 10:00 to 14:40 LST on 2 December 2016. The vehicle moves at a speed of $13.7 \mathrm{~m} \mathrm{~s}^{-1}$ on the $162.4 \mathrm{~km}$ route. The road material is classified as asphalt $(72.2 \%)$ and concrete $(27.8 \%)$, while the road structure is classified as overground $(86.2 \%)$, bridge $(10.4 \%)$, underpass $(0.6 \%)$, and tunnel $(2.8 \%)$ roads (Table 7). The road elevation is observed using the global po- (a) Backscattering coefficient (Jungnang)
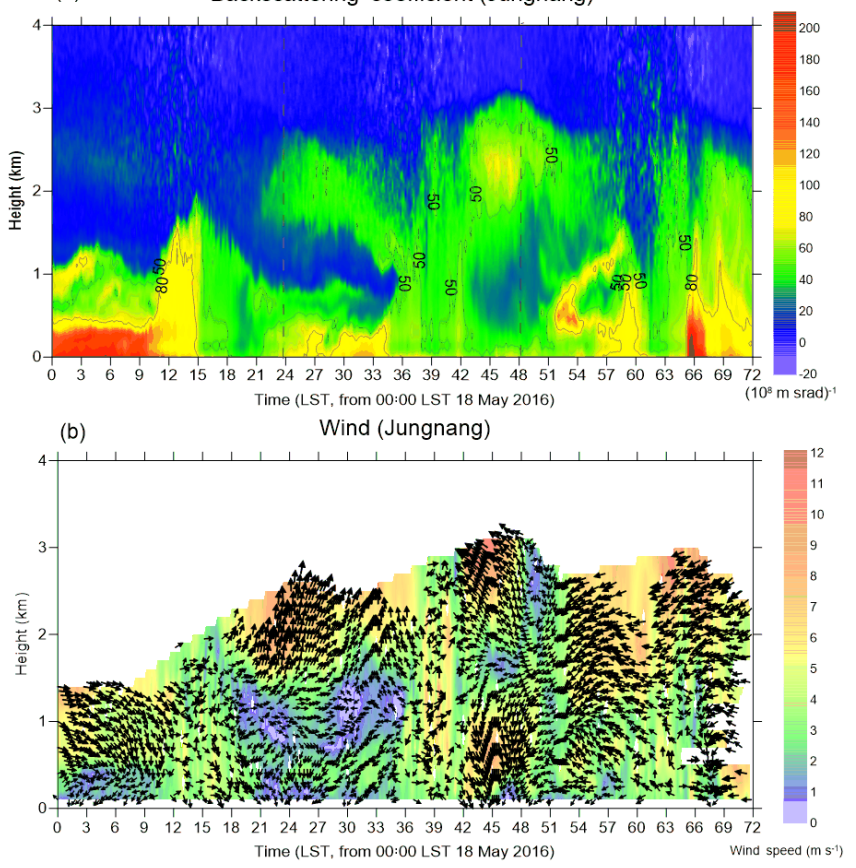

Figure 8. Time-height cross sections of (a) attenuated backscatter obtained with a ceilometer and (b) wind speed and direction obtained with a wind lidar at the Jungnang Station for the period from 00:00 LST on 18 May to 00:00 LST on 21 May 2016.

sitioning system sensor. The surface temperature is related to the road elevation, surface material, road structure, skyview, and horizontal distribution of the surface land use. The surface temperature over the concrete road is lower than that over the asphalt road due to the difference in albedo and diffusivity (Fig. 11). The albedo and thermal properties of typical road surface materials are obtained in advance based on a special experiment using a four-component net radiometer and surface temperature. The sky view is determined by a fish-eye view image; that over a bridge is higher than that over an overground due to the difference of thermal heat capacity and heat transfer processes. Based on these data, the roadway sections vulnerable to icing on highways and major principal roads can be determined by linearly detrended road surface temperature analysis (Fig. 12). These vulnerabilities can be used to provide alarms or advisories to drivers. Also, these data will help to improve the road surface temperature and status prediction system (Park et al., 2014b). Statistical and physical approaches to determine road sections vulnerable to icing are now available. 

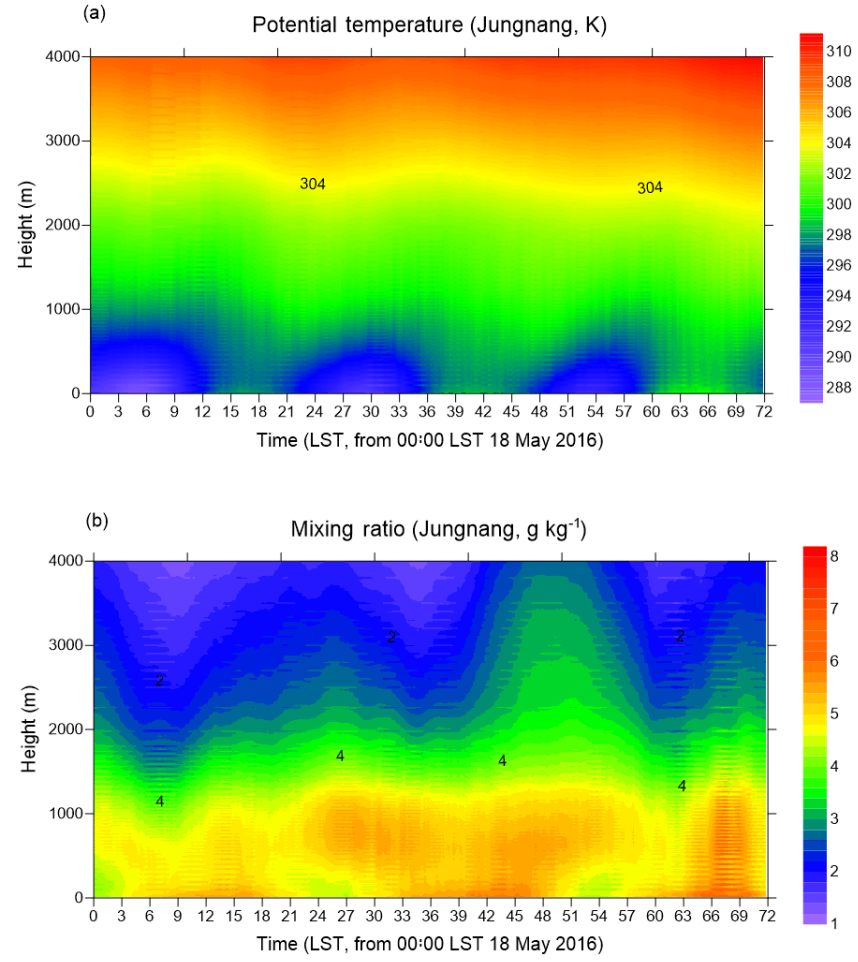

Figure 9. Time-height cross sections of the (a) potential temperature and (b) mixing ratio obtained with a microwave radiometer at the Jungnang Station for the period from 00:00 LST on 18 May to 00:00 LST on 21 May 2016.

Table 7. Coverage fraction of road material and structure on the roadway route observed between 10:00 and 14:40 LST on 2 December 2016.

\begin{tabular}{llr}
\hline Material & Structure & Coverage (\%) \\
\hline \multirow{2}{*}{ Asphalt } & Overground (AG) & 67.18 \\
& Bridge (AB) & 3.77 \\
& Underpass (AU) & 0.57 \\
& Tunnel (AT) & 0.67 \\
\hline \multirow{2}{*}{ Concrete } & Overground (CG) & 19.04 \\
& Bridge (CB) & 6.59 \\
& Underpass (CU) & 0.00 \\
& Tunnel (CT) & 2.18 \\
\hline Total & & 100.00 \\
\hline
\end{tabular}

\section{Data processing}

\subsection{Metadata}

To understand the observational environment of the stations in detail and maintain the networks and stations more efficiently, metadata of the UMS-Seoul are standardized based on a comparison with data established by the World Meteorological Organization, the Korea Meteorological Admin-
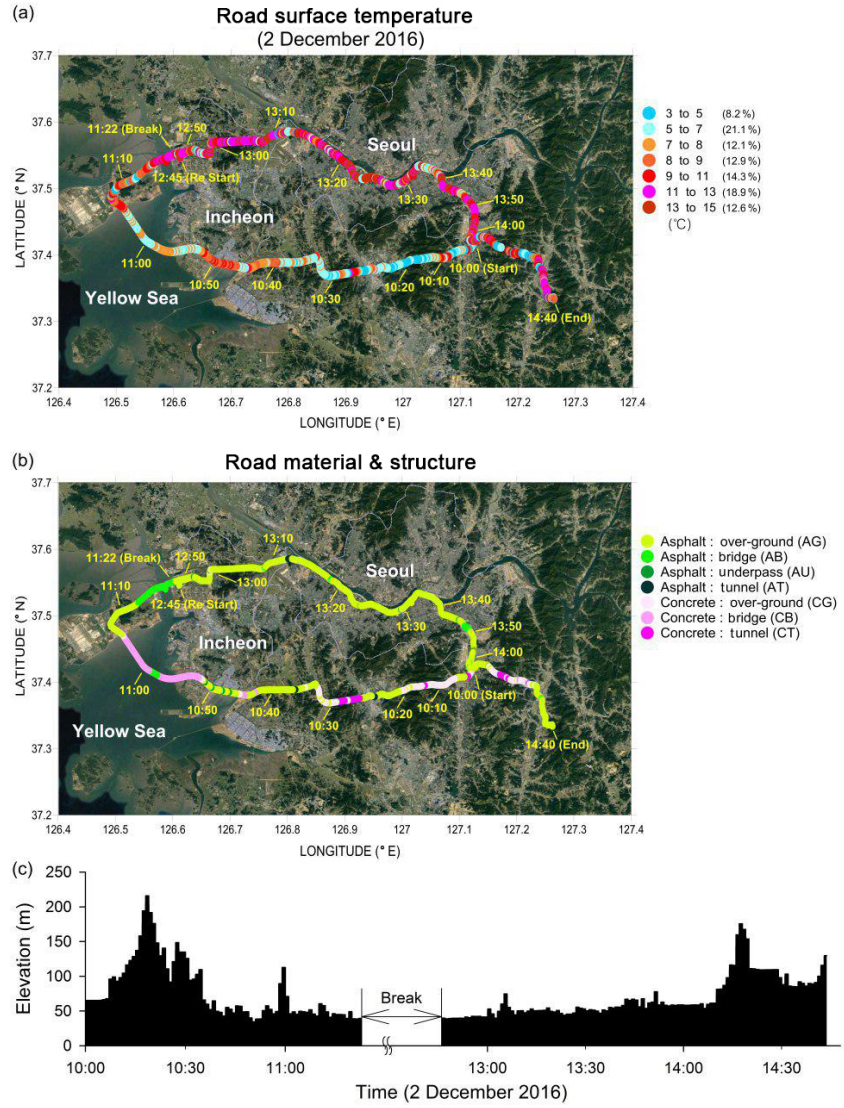

Figure 10. (a) Road surface temperature, (b) road surface material and structure, and (c) elevation on the roadway obtained with a mobile road weather vehicle in the Seoul Metropolitan Area for the period from 10:00 to 14:40 LST on 2 December 2016.

istration, and previous studies (WMO, 2008; KMA, 2013; Muller et al., 2013; Song et al., 2014). The UMS-Seoul metadata include network and station information composed of general, local-scale, micro-scale, and visual information (Muller et al., 2013). Figure 13 shows the structure of UMSSeoul metadata and an example of general station information metadata (Song et al., 2014). The metadata contain static information, such as urban structure, surface land cover, metabolism, roof type (roofing tile, slope angle, and material), telecommunication between instrument and data server, moisture/heat sources, and traffic and updated information on environmental changes, maintenance, replacement, and/or the calibration of sensors. The urban structure includes information such as spaces between buildings, building density, street widths, tree species, and tree height information (Muller et al., 2013). The telecommunication for data transmission includes telecommunication type, name, password, network owner, and contact person. The network and station metadata are required to be documented and updated every year. These metadata are documented based on an on-site survey and panoramic photos taken at the station, fish-eye 


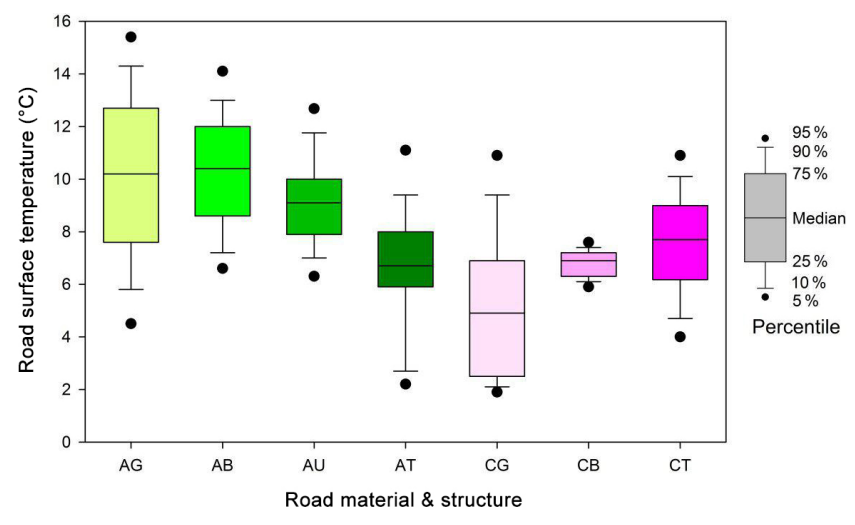

Figure 11. Box plot of the observed road surface temperatures according to road material and structure on the roadway obtained with a mobile road weather vehicle in the Seoul Metropolitan Area for the period from 10:00 to 14:40 LST on 2 December 2016. The first character stands for road material type: A, asphalt; $\mathrm{C}$, concrete. The second character denotes the road structure type: G, overground; B, bridge; $\mathrm{U}$, underpass; and $\mathrm{T}$, tunnel.

view image, satellite image, map investigation, and literature investigation.

\subsection{Data acquisition and display system}

All data are collected, displayed, and quality-checked in real time (Fig. 14). When the data are sampled on minute zero of every hour, they are transmitted into a main server within 5 min using machine-to-machine (M2M) technology and code division multiple access (CDMA) or a long-term evolution (LTE) telecommunication network; the subsequent automated quality checks are conducted within $10 \mathrm{~min}$. The data are then ready to be distributed to the relevant users. UMS-Seoul quality checks are divided into automated and manual steps. Because each instrument has its own data characteristics with its own format, temporal resolution, and vertical resolution, it should have its own quality check algorithm. For example, the wind lidar has the following quality check procedure: carrier-to-noise check, data availability check, and vertical gradient of horizontal wind check in addition to the basic missing check (Park and Choi, 2016).

Not only the current values and time series for the automated quality-checked data are displayed in real time but also the derived variables, such as albedo, atmospheric boundarylayer height, and net radiative flux, to monitor the past and current states of atmospheric variables.

Data obtained with UMS-Seoul are now available to limited researchers and users in South Korea but will be available to all relevant researchers around the world soon. (a)

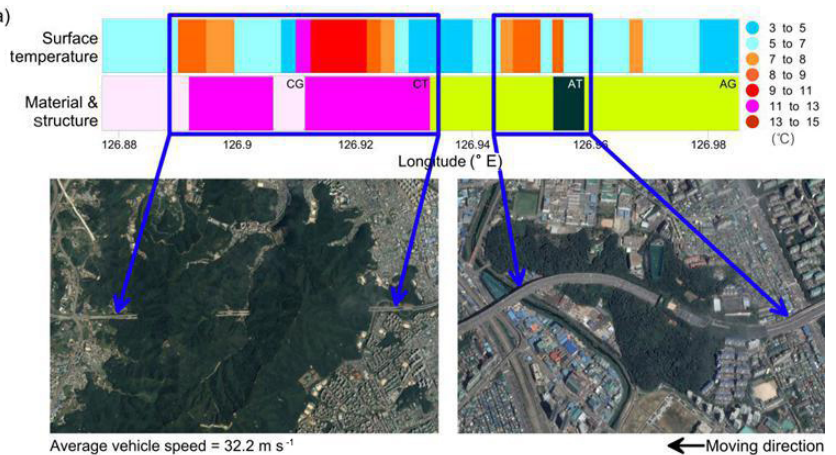

(b)

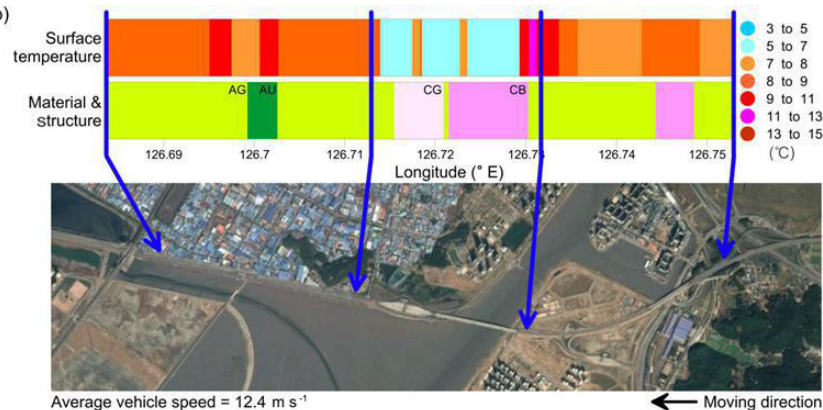

Figure 12. Detailed surface temperature and material and structure based on a satellite image at road sections (a) from 126.88 to $126.98^{\circ} \mathrm{E}$ and (b) from 126.68 to $126.76^{\circ} \mathrm{E}$ in Fig. 10. The first character stands for the road material type: A, asphalt; C, concrete. The second character denotes the road structure type: G, overground; $\mathrm{B}$, bridge; U, underpass; and $\mathrm{T}$, tunnel.

\section{Summary and discussion}

The UMS-Seoul is one of the most intensively integrated urban observation networks in the world for user-specific meteorological information services, such as flash floods, road status and surface temperature, urban heat islands, and air quality, based on the retrieval of high-resolution and highquality meteorological data in the SMA in South Korea.

Although the existing surface meteorological observation network provides very high-resolution information, it focuses primarily on surface meteorology and radar echoes. The UMS-Seoul includes additional 14 surface energy balance systems, 2 aerosol lidar systems and 2 ceilometers, 6 wind lidars, 7 microwave radiometers, and meteorological observation systems. The surface energy balance system determines the surface energy forcing and physical, optical, and thermal properties according to the urban surface land cover in detail. The ceilometers and aerosol lidars provide the aerosol vertical profile and the boundary-layer structure, while wind lidars and microwave radiometers provide the vertical profiles of wind, temperature, humidity, and liquid water in real time. The AP observation system includes road, water quality, greenhouse gas, and mosquito data to improve the performance of weather information customized based on the user demand. The metadata are standardized to pro- 
(a)

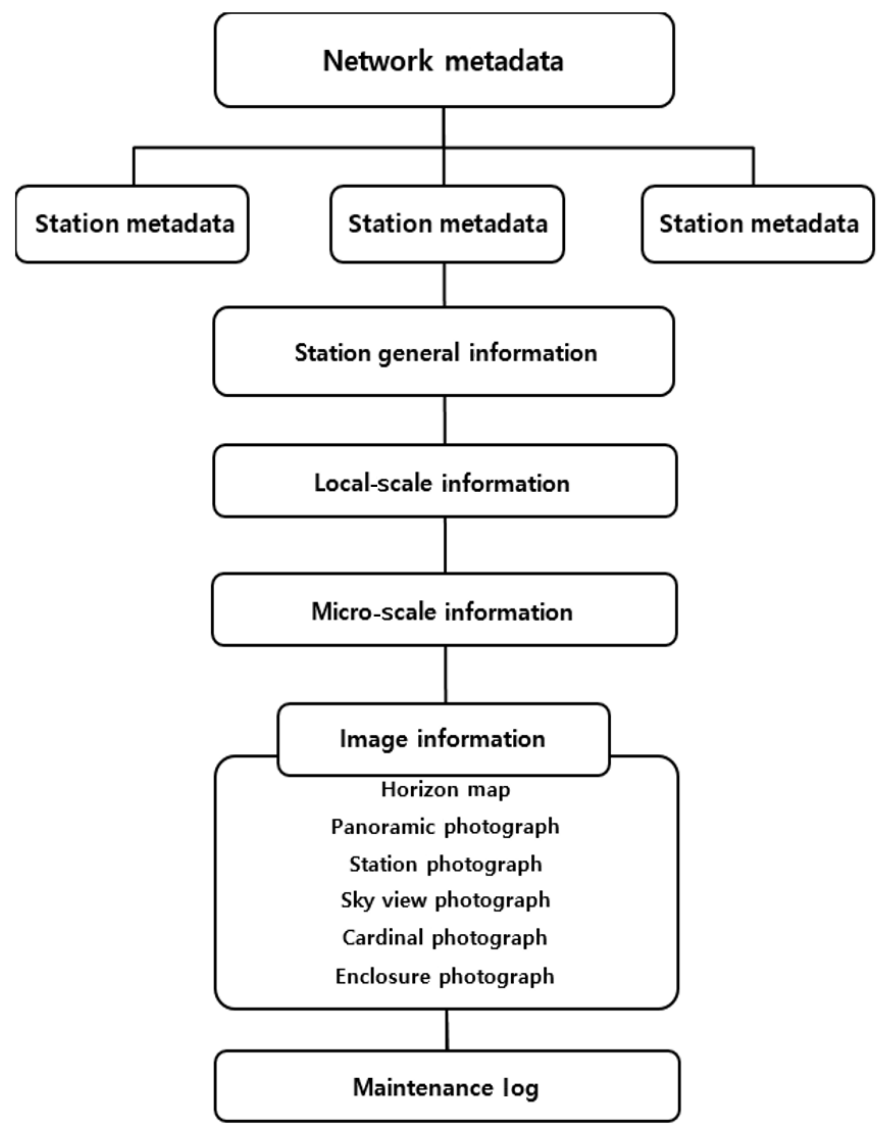

(b)
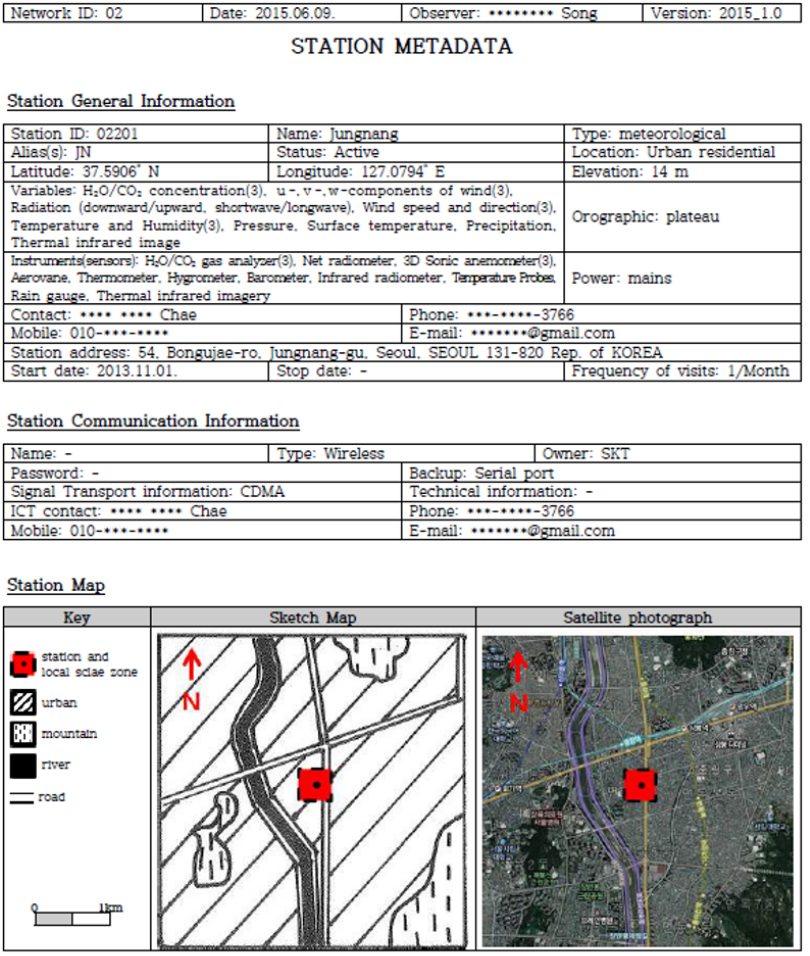

Additional Comments (Station changes / Remarks)

- 2013.11.01. : Observation start

- 2014.07.14. : Addition of Rain gauge

2015.06.09. : Photograph update

Camera's position >

Panoramic(Cardinal) photograph / Station photography - direction : back of the ceilometer NW from instruments

Figure 13. (a) The structure of UMS-Seoul metadata and station metadata and (b) an example of station general information metadata for the surface energy balance system at Jungnang Station.

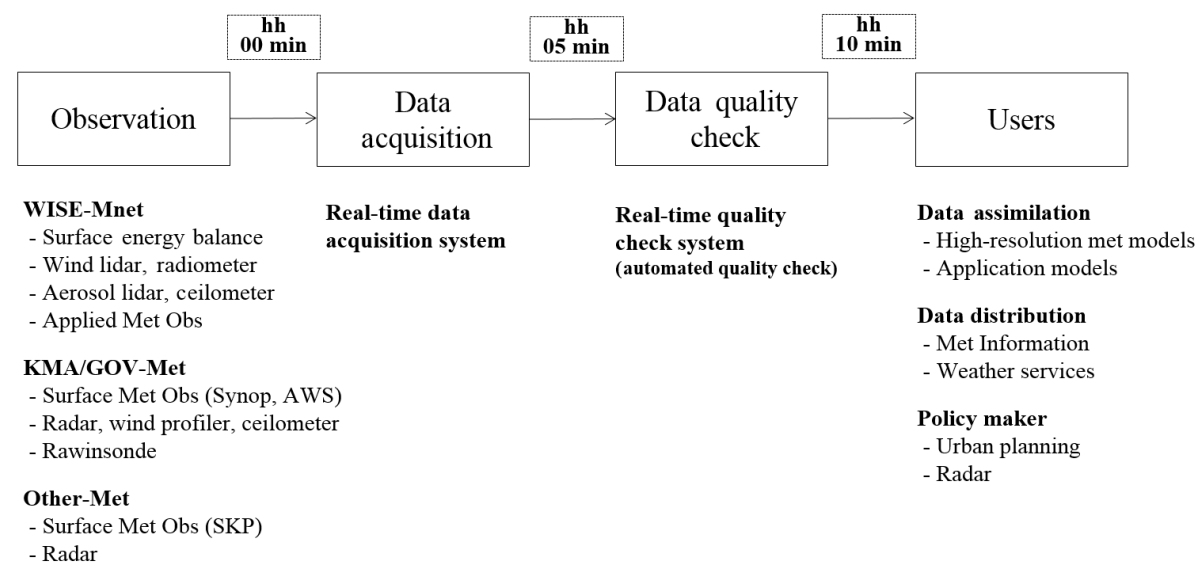

Figure 14. UMS-Seoul data flow from observation to users via data acquisition and quality checks.

vide detailed network and station information. Also, realtime data acquisition, quality checks, and a display system are constructed to monitor the horizontal and vertical distribution of meteorological variables and maintain observed data. Qualified data are then ready to be distributed to re- searchers or policy makers. The UMS-Seoul data help to understand the cause and effect for each weather event more deeply and to produce a 3-D meteorological field with sufficiently high resolution and quality. 
In addition to fixed meteorological observation systems, intensive upper-air observation experimental campaigns are conducted repeatedly. They are aimed at a deeper comprehension of the urban meteorology and produce the data necessary for a high-resolution meteorological information service. The station locations are optimized using the analysis of the observing system simulation experiment (OSSE), a model-based experiment for the purpose of assessing the potential impact of the would-be observation station for any instrument and/or sensor (Zhang and $\mathrm{Pu}, 2010$ ) providing a more stable meteorological information service. Based on the OSSE results, some stations or instruments might be added, removed, or moved to other locations.

As a leading urban experimental complex, the UMSSeoul is expected to contribute to the improvement of highresolution meteorological information technology and the alleviation of damage from disastrous weather phenomena in high-population-density urban areas around the world.

Data availability. Most data obtained with UMS-Seoul can be provided upon request; for further inquiries please contact either Moon-Soo Park (ngeograph2@gmail.com) or Sung-Hwa Park (torch1407@gmail.com).

Competing interests. The authors declare that they have no conflict of interest.

Acknowledgements. This work was funded by the Weather Information Service Engine (WISE) Program of the Korea Meteorological Administration under grant KMIPA-2012-0001-01. All data used in this study were produced under the WISE Program.

Edited by: D. Ruffieux

Reviewed by: two anonymous referees

\section{References}

Allwine, K. J., Shinn, J. H., Streit, G. E., Clawson, K. L., and Brown, M. J.: Overview of Urban 2000: a multiscale field study of dispersion through an urban environment, B. Am. Meteorol. Soc., 83, 521-536, doi:10.1175/15200477(2002)083<0521:OOUAMF>2.3.CO;2, 2002.

Arnfield, A. J.: Two decades of urban climate research: a review of turbulence, exchange of energy and water, and urban heat island, Int. J. Climatol., 23, 1-26, doi:10.1002/joc.859, 2003.

Aubinet, M., Vesala, T., and Papale, D.: Eddy covariance: A practical guide to measurement and data analysis, Springer, Dordrecht Heidelberg London New York, 438 pp., 2012.

Auer, A. H.: Correlation of land use and cover with meteorological anomalies, J. Appl. Meteorol., 17, 636-643, doi:10.1175/15200450(1978)017<0636:COLUAC>2.0.CO;2, 1978.
Baklanov, A.: Overview of the European project FUMAPEX, Atmos. Chem. Phys., 6, 2005-2015, doi:10.5194/acp-6-2005-2006, 2006.

Baklanov, A., Mestayer, P. G., Clappier, A., Zilitinkevich, S., Joffre, S., Mahura, A., and Nielsen, N. W.: Towards improving the simulation of meteorological fields in urban areas through updated/advanced surface fluxes description, Atmos. Chem. Phys., 8, 523-543, doi:10.5194/acp-8-523-2008, 2008.

Barlow, J. F., Dunbar, T. M., Nemitz, E. G., Wood, C. R., Gallagher, M. W., Davies, F., O'Connor, E., and Harrison, R. M.: Boundary layer dynamics over London, UK, as observed using Doppler lidar during REPARTEE-II, Atmos. Chem. Phys., 11, 2111-2125, doi:10.5194/acp-11-2111-2011, 2011.

Basara, J. B., Illston, B. G., Fiebrich, C. A., Browder, P. D., Morgan, C. R., McCombs, A., Bostic, J. P., McPherson, R. A., Schroeder, A. J., and Crawford, K. C.: The Oklamhoma city micronet, Meteorol. Appl., 18, 252-261, doi:10.1002/met.189, 2011.

Bornstein, R. D.: Observations of the urban heat island effect in New York City, J. Appl. Meteorol., 7, 575-582, doi:10.1175/1520-0450(1968)007<0575:OOTUHI>2.0.CO;2, 1968.

Bornstein, R. D. and Lin, Q.: Urban heat islands and summertime convective thunderstorms in Atlanta: three case studies, Atmos. Environ., 34, 507-516, doi:10.1016/S1352-2310(99)00374-X, 2000.

Carrio, G., Cotton, W. R., and Cheng, W.: Urban growth and aerosol effects on convection over Houston, Atmos. Res., 96, 560-574, doi:10.1016/j.atmosres.2010.01.005, 2010.

Cayetano, M. G., Kim, Y. J., Jung, J. S., Batmunkh, T., Lee, K. Y., Kim, K. C., Kim, D. G., Lee, S. J, Kim, J. S., and Chang, L. S.: Observed chemical characteristics of long-range transported particles at a marine background site in Korea, J. Air Waste Ma., 61, 1192-1203, doi:10.1080/10473289.2011.604001, 2011.

Cha, Y.-M., Lee, H.-W., and Lee, S.-H.: Impacts of the highresolution sea surface temperature distribution on modeled snowfall formation over the Yellow Sea during a cold-air outbreak, Weather Forecast., 26, 487-503, doi:10.1175/WAF-D-1005019.1, 2011

Chae, J.-H., Park, M.-S., and Choi, Y.-J.: The WISE quality control systems for integrated meteorological sensor data, Atmosphere. Korean Meteorological Society, 24, 445-456, doi:10.14191/Atmos.2014.24.3.445, 2014.

Cheng, M. T. and Tsai, Y. I.: Characterization of visibility and atmospheric aerosols in urban, suburban, and remote areas, Sci. Total Environ., 263, 101-114, doi:10.1016/S0048-9697(00)006707, 2000

Choi, Y., Kang, S.-L., Hong, J., Grimmond, S., and Davis, K. J.: A next-generation weather information service engine (WISE) customized for urban and surrounding rural area, B. Am. Meteorol Soc., 94, ES114-117, doi:10.1175/BAMS-D-12-00217.1, 2013.

Christen, A. and Vogt, R.: Energy and radiation balance of a central European city, Int. J. Climatol., 24, 1395-1421, doi:10.1002/joc.1074, 2004.

Chung, Y. S. and Kim, H. S.: Observations of massive air-pollution transport and associated air quality in the Yellow Sea region, Air Qual. Atmos. Health, 1, 69-79, doi:10.1007/s11869-008-0014-y, 2008.

Cros, B., Durand, P., Cachier, H., Drobinski, Ph., Frejafon, E., Kottmeier, C., Perros, P. E., Peuch, V.-H., Ponche, J.-L., 
Robin, D., Said, F., Toupance, G., and Wortham, H.: The ESCOMPTE program: an overview, Atmos. Res., 69, 241-279, doi:10.1016/j.atmosres.2003.05.001, 2004.

Davenport, A. G., Grimmond, C. S. B., Oke, T. R., and Wieringa, J.: Estimating the roughness of cities and sheltered country, in: Proceedings of the Twelfth Conference on Applied Climatology, 8-12 May 2000, Asheville, Amer. Meteor. Soc., 96-99, 2000.

Demographia: Demographia world urban areas, Built up urban areas or world agglomerations, 11th edit, Demographia, Illinois, USA, 133 pp., 2015.

Dixon, P. and Mote, T.: Patterns and causes of Atlanta's urban heat island-initiated precipitation, J. Appl. Meteorol., 42, 1273-1284, doi:10.1175/1520-0450(2003)042<1273:PACOAU>2.0.CO;2, 2003.

Dudhia, J.: Numerical study of convection observed during the winter monsoon experiment using a mesoscale two-dimensional model, J. Atmos. Sci., 46, 3077-3107, doi:10.1175/15200469(1989)046<3077:NSOCOD>2.0.CO;2, 1989.

Emeis, S., Schafer, K., and Munkel, C.: Surface-based remote sensing of the mixing-layer height - a review, Meteorol. Z., 17, 621630, doi:10.1127/0941-2948/2008/0312, 2008.

Eresmaa, N., Karppinen, A., Joffre, S. M., Räsänen, J., and Talvitie, H.: Mixing height determination by ceilometer, Atmos. Chem. Phys., 6, 1485-1493, doi:10.5194/acp-6-1485-2006, 2006.

Freitas, E. D., Rozoff, C. M., Cotton, W. R., and Silva Dias, P. L.: Interactions of an urban heat island and sea-breeze circulations during winter over the metropolitan area of Sao Paulo, Brazil, Bound.-Lay. Meteorol., 122, 43-65, doi:10.1007/s10546006-9091-3, 2007.

Grimmond, C. S. B.: Progress in measuring and observing the urban atmosphere, Theor. Appl. Climatol., 84, 1-22, doi:10.1007/s00704-005-0140-5, 2006.

Grimmond, C. S. B., Salmond, J. A., Oke, T. R., Offerle, B., and Lemonsu, A.: Flux and turbulence measurements at a densely built-up site in Marseille: heat, mass (water and carbon dioxide), and momentum, J. Geophys. Res., 109, D24101, doi:10.1029/2004JD004936, 2004.

Grimmond, C. S. B., Best, M., Barlow, J., Arnfield, A. J., Baik, J.-J., Baklanov, A., Belcher, S., Bruse, M., Calmet, I, Chen, F., Clark, P., Dandou, A., Erell, E., Fortuniak, K., Hamdi, R., Kanda, M., Kawai, T., Kondo, H., Krayenhoff, S., Lee, S.-H., Limor, S.-B., Martilli, A., Masson, V., Miao, S., Mills, G., Moriwaki, R., Oleson, K., Porson, A., Sievers, U., Tombrou, M., Voogt, J., and Williamson, T.: Urban surface energy balance models: Model characteristics and methodology for a comparison study, in: Meteorological and Air Quality Models for Urban Areas, edited by: Baklanov, A., Grimmond, S., Mahura, A., and Athanassiadou, M., Springer-Verlag, 97-123, doi:10.1007/9783-642-00298-4_11, 2009.

Han, J.-Y., Baik, J.-J., and Lee, H.: Urban impacts on precipitation, Asia-Pac. J. Atmos. Sci., 50, 17-30, doi:10.1007/s13143-0140016-7, 2014.

Harman, I. N. and Belcher, S. E.: The surface energy balance and boundary layer over urban street canyon, Q. J. Roy. Meteor. Soc., 132, 2749-2768, doi:10.1256/qj.05.185, 2006.

Hicks, B. B., Callahan, W. J., Pendergrass III, W. R., Dobosy, R. J., and Novakovskaia, E.: Urban turbulence in space and time, J. Appl. Meteorol. Clim., 51, 205-218, doi:10.1175/JAMC-D-11015.1, 2012.
Jee, J.-B., Jang, M., Yi, C., Zo, I.-S., Kim, B.-Y., Park, M.-S., and Choi, Y.-J.: Sensitivity analysis of the high-resolution WISEWRF model with the use of surface roughness length in Seoul Metropolitan Area, Atmosphere. Korean Meteorological Society, 26, 111-126, doi:10.14191/Atmos.2016.26.1.111, 2016.

Jeong, J. and Park, R.: A study of the effects of SST deviations on heavy snowfall over the Yellow Sea, Atmosphere. Korean Meteorological Society, 23, 161-169, doi:10.14191/Atmos.2013.23.2.161, 2013.

Kalnay, E. and Cai, M.: Impacts of urbanization and land-use change on climate, Nature, 423, 528-531, doi:10.1038/nature01675, 2003.

Khan, S. M. and Simpson, R. W.: Effect of a heat island on the meteorology of a complex urban airshed, Bound.-Lay. Meteorol., 100, 487-506, doi:10.1023/A:1019284332306, 2001.

Kim, E., Ra, I., Rhee, K. H., and Kim, C. S.: Estimation of realtime flood risk on road based on rainfall calculated by the revised method of missing rainfall, Sustainability, 6, 6418-6431, doi:10.3390/su6096418, 2014.

Kim, W., Miyata, A., Ashraf, A., Maruyama, A., Chidthaisong, A., Jaikaeo, C., Komori, D., Ikoma, E., Sakurai, G., Seoh, H.-H., Son, I. C.,Cho, J., Kim, J., Ono, K., Nusit, K., Moon, K. H., Mano, M., Yokozawa, M., Baten, M. A., Sanwangsri, M., Toda, M., Chaun, N., Polsan, P., Yonemura, S., Kim, S.-D., Miyazaki, S., Kanae, S., Phonkasi, S., Kammales, S., Takimoto, T., Nakai, T., Iizumi, T., Surapipith, V., Sonklin, W., Lee, Y., Inoue, Y., Kim, Y., and Oki, T.: FluxPro as a realtime monitoring and surveilling system for eddy covariance flux measurement, J. Agr. Meteorol., 71, 32-50, doi:10.2480/agrmet.D-14-00034, 2015.

Kim, Y. H. and Baik, J.-J.: Spatial and temporal structure of the urban heat island in Seoul, J. Appl. Meteorol., 44, 591-605, doi:10.1175/JAM2226.1, 2005.

Kim, Y.-H., Choi, D.-Y., and Chang, D.-E.: Characteristics of urban meteorology in Seoul Metropolitan Area of Korea, Atmosphere. Korean Meteorological Society, 21, 257-271, 2011.

KMA: Manual of management and research on meta information, Korea Meteorological Administration, Seoul, Korea, 2013.

Koskinen, J. T., Poutiainen, J., Schultz, D. M., Joffre, S., Koistinen, J., Saltikoff, E., Gregow, E., Turtiainen, H., Dabberdt, W. F., Damski, J., Eresmma, N., Goke, S., Hyvarinen, O., Jarvi, L., Karppinen, A., Kotro, J., Kuitunen, T., Kukkonen, J., Kulmala, M., Moisseev, D., Nurmi, P., Pohjola, H., Pylkko, P., Vesala, T., and Viisanen, Y.: The Helsinki testbed. A mesoscale measurement, research, and service platform, B. Am. Meteorol. Soc., 92, 325-342, doi:10.1175/2010BAMS2878.1, 2011.

Kuttler, W., Weber, S., Schonnefeld, S., and Hesselschwerdt, A.: Urban/rural atmospheric water vapor, pressure differences and urban moisture excess in Krenfeld, Germany, Int. J. Climatol., 27, 2005-2015, doi:10.1002/joc.1558, 2007.

Kwon, T. H., Park, M.-S., Yi, C., and Choi, Y. J.: Effects of different averaging operators on the urban turbulent fluxes, Atmosphere. Korean Meteorological Society, 24, 197-206, doi:10.14191/Atmos.2014.24.2.197, 2014.

Landsberg, H. E: The Urban Climate, Academic Press, New York, USA, 275 pp., 1981.

Lee, S.-H. and Park, S.-U.: A vegetated urban canopy model for meteorological and environmental modelling, Bound.-Lay. Meteor., 126, 73-102, doi:10.1007/s10546-007-9221-6, 2008. 
Leuning, R.: The correct form of the Webb, Pearman and Leuning equation for eddy fluxes of trace gases in steady and non-steady state, horizontally homogeneous flows, Bound-Lay. Meteorol., 123, 263-267, doi:10.1007/s10546-006-9138-5, 2007.

Lin, C.-Y., Chen, W.-C., Chang, P.-L., and Sheng, Y.-F.: Impact of the urban heat island effect on precipitation over a complex geographical environment in Northern Taiwan, J. Appl. Meteorol. Clim., 50, 339-353, doi:10.1175/2010JAMC2504.1, 2011.

Macdonald, R. W., Griffiths, R. F., and Hall, D. J.: An improved method for estimation of surface roughness of obstacle arrays, Atmos. Environ., 32, 1857-1864, doi:10.1016/S13522310(97)00403-2, 1998.

Masson, V.: Urban surface modeling and the meso-scale impact of cities, Theor. Appl. Climatol., 84, 35-45, doi:10.1007/s00704005-0142-3, 2006.

Monteith, J. L. and Unsworth, M. H.: Principles of Environmental Physics, 2nd Ed., Edward Arnold, New York, USA, 291 pp., 1990.

Muller, C. L., Chapman, L., Grimmond, C. S. B., Young, D. T., and Cai, X.-M.: Toward a standardized metadata protocol for urban meteorological networks, B. Am. Meteorol. Soc., 94, 11611185, doi:10.1175/BAMS-D-12-00096.1, 2013.

Nakatani, T., Shoji, Y., Misumi, R., Saito, K., Seino, N., Seko, H., Fujiyoshi, Y., and Nakamura, I.: WWRP RDP science plan: Tokyo Metropolitan Area Convection Study for Extreme Weather Resilient Cities (TOMACS), WWRP JSC Doc. 4.6, Switzerland, 26 pp., 2013.

Nakatani, T., Misumi, R., Shoji, Y., Saito, K., Seko, H., Seino, N., Suzuki, S., Shusse, Y., Maesaka, T., and Sugawara, H.: Tokyo Metropolitan Area Convection Study for Extreme Weather Resilient Cities, B. Am. Meteorol. Soc., 96, ES123-ES126, doi:10.1175/BAMS-D-14-00209.1, 2015.

Nichol, J. E., Wong, M. S., and Wang, J.: A 3-D aerosol and visibility information system for urban areas using remote sensing and GIS, Atmos. Environ., 44, 2501-2506, doi:10.1016/j.atmosenv.2010.04.036, 2010.

Nordbo, A., Jarvi, L., and Vesala, T.: Revised eddy covariance flux calculation methodologies - effect on urban energy balance, Tellus B, 64, 18184, doi:10.3402/tellusb.v64i0.18184, 2012.

Nunez, M. and Oke, T. R.: The energy balance of an urban canyon, J. Appl. Meteorol., 16, 11-19, doi:10.1175/15200450(1977)016<0011:TEBOAU>2.0.CO;2, 1977.

OFCM: Urban meteorology meeting weather needs in the urban community, Office of the Federal Coordinator for Meteorological Services and Supporting Research, FCM-R22-2004, Washington, DC, USA, 20 pp., 2004.

Oke, T. R.: City size and the urban heat island, Atmos. Environ., 7, 769-779, doi:10.1016/0004-6981(73)90140-6, 1973.

Oke, T. R.: Initial guidance to obtain representative meteorological observations at urban sites, IOM Rep. 81, WMO/TD-No. 1250, Switzerland, 47 pp., 2004.

Park, D. W., Nikhil, N. V., and Lee, S. R.: Landslide and debris flow susceptibility zonation using TRIGRS for the 2011 Seoul landslide event, Nat. Hazards Earth Syst. Sci., 13, 2833-2849, doi:10.5194/nhess-13-2833-2013, 2013.

Park, M.-S., and Choi, M.-H.: Development of a quality check algorithm for the WISE pulsed Doppler wind lidar, Atmosphere. Korean Meteorological Society, 26, 461-471, doi:10.14191/Atmos.2016.26.3.461, 2016.
Park, M.-S., Joo, S. J., and Lee, C. S.: Effects of an urban park and residential area on the atmospheric $\mathrm{CO}_{2}$ concentration and flux in Seoul, Korea, Adv. Atmos. Sci., 30, 503-514, doi:10.1007/s00376-012-2079-7, 2013.

Park, M.-S., Joo, S. J., and Park, S.-U.: Carbon dioxide concentration and flux in an urban residential area in Seoul, Korea, Adv. Atmos. Sci., 31, 1101-1112, doi:10.1007/s00376-013-3168-y, 2014a.

Park, M.-S., Joo, S. J., and Son, Y. T.: Development of road surface temperature prediction model using the Unified Model output (UM-Road), Atmosphere. Korean Meteorological Society, 24, 471-479, doi:10.14191/Atmos.2014.24.4.471, 2014b.

Park, S.-U., Choe, A., and Park, M.-S.: Asian dust depositions over the Asian region during March 2010 estimated by ADAM2, Theor. Appl. Climatol., 105, 129-142, doi:10.1007/s00704-0100380-x, 2011.

Park, S.-U., Cho, J.-H., and Park, M.-S.: Analyses of high aerosol concentration events (dense haze/mist) occurred in East Asia during 10-16 January 2013 using the data simulated by the Aerosol Modeling System, Int. J. Chem., 3, 10-26, 2013.

Peterson, J. T., Flowers, E. C., and Rudisill, J. H.: Urban-rural solar radiation and atmospheric turbidity measurements in the Los Angeles Basin, J. Appl. Meteorol., 17, 1595-1609, doi:10.1175/1520-0450(1978)017<1595:URSRAA>2.0.CO;2, 1978.

Pielke, R. A.: Mesoscale Meteorological Modeling, International Geophysics Series 78. Academic Press, California, USA, 676 pp., 2002.

Razafindrabe, B. H. N., Parvin, G. A., Surjan, A., Takeuchi, Y., and Shaw, R.: Climate disaster resilience: focus on coastal urban cities in Asia, Asian J. Environ. Disaster Management, 1, 101-116, doi:10.3850/s179392402009000088, 2009.

Robaa, S. M.: Urban-rural solar radiation loss in the atmosphere of Greater Cairo region, Egypt, Energy Conv. Manage., 50, 194202, doi:10.1016/j.enconman.2008.06.024, 2009.

Rotach, M. W., Vogt, R., Bernhofer, C., Batchvarova, E., Christen, A., Clappier, A., Feddersen, B., Gryning, S.-E., Martucci, G., Mayer, H., Mitev, V., Oke, T. R., Parlow, E., Richner, H., Roth, M., Roulet, Y.-A., Ruffieux, D., Salmond, J. A., Schatzmann, M., and Voogt, J. A.: BUBBLE- an Urban Boundary Layer Meteorology Project, Theor. Appl. Climatol., 81, 231-261, doi:10.1007/s00704-004-0117-9, 2005.

Roth, M.: Review of atmospheric turbulence over cities, Q. J. Roy. Meteor. Soc., 126, 941-990, doi:10.1002/qj.49712656409, 2000.

Ryu, Y.-H. and Baik, J.-J.: Daytime local circulations and their interactions in the Seoul Metropolitan Area, J. Appl. Meteorol. Clim., 52, 784-801, doi:10.1175/JAMC-D-12-0157.1, 2013.

Santillan-Soto, N., Garcia-Gueto, R., Haro-Rincon, Z., OjedaBenitez, S., Quintero-Nunez, M., and Velazquez-Limon, N.: Radiation balance of urban materials and their thermal impact in semi-desert region: Mexiali, Mexico study case, Atmosphere. Basel, 6, 1578-1589, doi:10.3390/atmos6101578, 2015.

Schroeder, A. J., Basara, J. B., and Illston, B. G.: Challenges associated with classifying urban meteorological stations: The Oklahoma city micronet example, Open Atmos. Sci. J., 4, 88-100, doi:10.2174/1874282301004010088, 2010.

Shepherd, J. M.: A review of current investigations of urbaninduced rainfall and recommendation for the future, Earth Interact., 9, 1-27, doi:10.1175/EI156.1, 2005. 
Singh, T., Khillare, P. S., Shridhar, V., and Agarwal, T.: Visibility impairing aerosols in the urban atmosphere of Delhi, Environ. Monit. Assess., 141, 67-77, doi:10.1007/s10661-007-98798, 2008.

Son, J.-Y., Lee, J.-T., Anderson, B., and Bell, M. L.: The impacts of heat waves on mortality in seven major cities in Korea, Environ. Health Perspect., 120, 566-571, doi:10.1289/ehp.1103759, 2012.

Song, T., Sun, Y., and Wang, Y.: Multilevel measurements of fluxes and turbulence over an urban landscape in Beijing, Tellus B, 65, 20421, doi:10.3402/tellusb.v65i0.20421, 2013.

Song, Y., Chae, J.-H., Choi, M.-H., Park, M.-S., and Choi, Y. J.: Standardization of metadata for urban meteorological observations, J. Korean Soc. Atmos. Environ., 30, 600-618, doi:10.5572/KOSAE.2014.30.6.600, 2014.

Stewart, I. D. and Oke, T. R.: Classifying urban climate field sites by local climate zones: The case of Nagano, Japan, 7th International Conference on Urban Climate, 29 June-3 July 2009, Yokohama, Japan, 2009.

Stewart, I. D. and Oke, T. R.: Local climate zones for urban temperature studies, B. Am. Meteorol. Soc., 93, 1879-1900, doi:10.1175/BAMS-D-11-00019.1, 2012.

Tan, J., Yang, L., Grimmond, C. S. B., Shi, J., Gu. W., Chang, Y., Hu, P., Sun J., Ao X., and Han, Z.: Urban Integrated Meteorological Observations Practice and Experience in Shanghai, China, B. Am. Meteorol. Soc., 96, 85-102, doi:10.1175/BAMS-D-1300216.1, 2015.

Unger, J.: Urban-rural air humidity differences in Szeged, Hungary, Int. J. Climatol., 19, 1509-1515, doi:10.1002/(SICI)10970088(19991115)19:13<1509::AID-JOC453>3.0.CO;2-P, 1999.

United Nations: World urbanization prospects: The 2014 revision. UN Population Division Department of Economic and Social Affairs, New York, USA, 2014.

United Nations: World population prospects: The 2015 revision, key findings and advance tables, UN Department of Economic and Social Affairs, Population Division, New York, USA, 2015.
Vickers, D. and Mahrt, L.: Quality control and flux sampling problems for tower and aircraft data, J. Atmos. Ocean. Tech., 14, 512-526, doi:10.1175/15200426(1997)014<0512:QCAFSP>2.0.CO;2, 1997.

Webb, E. K., Pearmann, G. I., and Leuning, R.: Correction of the flux measurements for density effects due to heat and water vapour transfer, Q. J. Roy. Meteor. Soc., 106, 85-100, doi:10.1002/qj.49710644707, 1980.

Werner, C.: Doppler wind lidar, in: Lidar Range-Resolved Optical Remote Sensing of the Atmosphere, edited by: Weitkamp, C., Springer, New York, USA, 325-354, 2005.

WMO: Guide to meteorological instruments and methods of observation WMO-No. 8, World Meteorological Organization, Switzerland, 2008.

Wood, C. R., Jarvi, L., Nordbo, A., Joffre, S., Drebs, A., Vihma, T., Hirsikko, A., Suomi, I., fortelius, C., O'Connor, E., Moiseev, D., Haapanala, S., Moilanen, J., Kangas, M., Karppinen, A., Veslal, T., and Kukkonen, J.: An overview of the urban boundary layer atmosphere network in Helsinki, B. Am. Meteorol. Soc., 94, 1675-1690, doi:10.1175/BAMS-D-12-00146.1, 2013.

Yang, C.-H., Park, M.-S., and Yoon, D.-G.: A road surface temperature prediction modelling for road weather information system, J. Korean Soc. Transport., 29, 123-131, 2011.

Yi, C., Kwon, T. H., Park, M.-S., Choi, Y. J., and Ahn, S. M.: A study on the roughness length spatial distribution in relation to the Seoul building morphology, Atmosphere. Korean Meteorological Society, 25, 339-351, doi:10.14191/Atmos.2015.25.2.339, 2015.

Zhang, L. and Pu, Z.: An observing system simulation experiment (OSSE) to assess the impact of Doppler Wind Lidar (DWL) measurements on the numerical simulations of a tropical cyclone, Adv. Meteorol., 2010, 743863, doi:10.1155/2010/743863, 2010. 